\title{
Okul Bazlı Bütçeleme (OBB) Uygulamasının Okul Geliştirme İşlevi Açısından Değerlendirilmesi*
}

\section{An Evaluation of School-Based Budgeting (SBB) Implementation from the Standpoint of School Development Function}

\author{
Betül BALKAR $^{* *}$ (i) Rabia ÖZTUZCU-KÜçÜKBERE ${ }^{* * *}$ (iD \\ Şahabettin AKŞAB***
}

Received: 10 October 2018

Research Article

Accepted: 02 January 2019

ABSTRACT: It was aimed to determine the opinions of school administrators on the implementation of SchoolBased Budgeting (SBB) and the contributions of SBB to school development in this study. The qualitative methods were used in this descriptive study. The study group consisted of 29 primary and secondary school administrators. After data of the study were obtained through semi structured interviews and focus group interviews. School administrators' opinions on authority and responsibilities of school management within SBB, usage of Ministry of National Education Information Systems fund monitoring module, setting school budget, contributions of SBB to school development and recommendations for improvement of SBB were analyzed through content analysis. The results of this study revealed that SBB implementation can serve for developing schools multidimensionally as a school development tool. It was also concluded that SBB should be structured in accordance with social, economic and cultural conditions of school and school environment. Based on the findings of the study, it is suggested that SBB can be performed differently depending on different needs of each school in an attempt to use it as a school development tool completely.

Keywords: school-based budgeting, school development, school administrators.

ÖZ: Bu araştırmada; okul yöneticilerinin Okul Bazlı Bütçeleme (OBB) uygulamasına ve OBB'nin okul gelişimine nasıl katkı sağlayabileceğine ilişkin görüşlerinin incelenmesi amaçlanmıştır. Bu betimsel çalışmada nitel araştırma yöntem ve tekniklerinin kullanılmıştır. Araştırmanın çalışma grubu, Gaziantep ilinde görev yapan 29 ilkokul ve ortaokul yöneticisinden oluşmaktadır. Araştırma verileri, yarı yapılandırılmış görüşmeler ve odak grup görüşmeleri aracılığıyla toplanmıştır. Elde edilen veriler, içerik analizi ile çözümlenmiştir. İçerik analizi sürecinde okul yöneticilerinin; OBB sürecinde okul yönetiminin yetki ve sorumlulukları, Milli Eğitim Bakanlığı Bilişim Sistemleri ödenek takip modülünün kullanımı, okul bütçesi oluşturulması ve OBB'nin okul gelişimine katkıları ile ilgili görüşleri ve OBB'nin geliştirilmesine yönelik önerileri analiz edilmiştir. Araştırmanın sonucunda, OBB uygulamasının okul geliştirme aracı olarak okulların çok boyutlu geliştirilmesine hizmet edebileceği ortaya çıkmıştır. Aynı zamanda, OBB kapsamında sosyal, ekonomik ve kültürel açıdan okulun ve okul çevresinin şartlarına uygun bir yapılanma sürecine gidilmesi gerektiği sonucuna varılmıştır. Araştırmanın bulgularına dayalı olarak, OBB'nin tam anlamıyla bir okul geliştirme aracı olarak kullanılabilmesi için okulların ihtiyaçlarına bağlı olarak farklılaştırılmış biçimlerde uygulanması önerilmektedir.

Anahtar kelimeler: okul bazlı bütçeleme, okul geliştirme, okul yöneticileri.

\footnotetext{
* This study was delivered as an oral presentation at the $13^{\text {th }}$ International Congress on Educational Administration which was held in Sivas on May 10-12, 2018.

** Corresponding Author: Assoc. Prof. Dr., University of Gaziantep, Gaziantep, Turkey, b.balkar@gmail.com, https://orcid.org/0000-0002-4774-9727

Teacher, Ministry of National Education, Gaziantep, Turkey, mhtlrb_2008@hotmail.com, https://orcid.org/00000001-5220-6332

***** Res. Asst., Middle East Technical University, Ankara, Turkey, sahabettin.aksab@gmail.com, https://orcid.org/0000-0001-9374-8007
}

Citation Information

Balkar, B., Öztuzcu-Küçükbere, R., \& Akşab, Ş. (2019). Okul Bazlı Bütçeleme (OBB) uygulamasının okul geliştirme işlevi açısından değerlendirilmesi. Kuramsal Eğitimbilim Dergisi [Journal of Theoretical Educational Science], $12(2), 727-756$. 


\section{Giriş}

Okullardaki eğitimin niteliğinin artırılması ve okulların sürekli değişen ihtiyaçlarının zamanında karşılanması yönündeki beklentiler, okulun iç ve dış paydaşlarının katılımıyla okul performansının çok yönlü bir şekilde geliştirilmesini gerekli kılmaktadır. Okul gelişiminin sağlanmasında, okul içi süreçlere odaklanıldığı kadar okul süreçlerini etkileyen sistem düzeyinde politikaların geliştirilmesine de odaklanılmaktadır. Bu nedenle birçok ülke, eğitimde verimliliği ve okul performansını artırmak amacıyla son yıllarda çeşitli finansman politikaları uygulamaktadır. Her okulun kayıtlı öğrenci sayısına göre bütçe oluşturmasına imkân veren öğrenci tabanlı bütçeleme (DeGrow, 2015), okulların performans bilgilerine göre fon dağıtımı yaparak harcamaların verimliliğini ve etkililiğini artırmayı amaçlayan performans temelli bütçeleme (Srithongrung, 2018) ve okul yönetimlerine okulun ve öğrencilerin ihtiyaçlarına göre, kaynak tahsisinde karar verme yetkisi veren okul bazlı bütçeleme (OBB) (Cheung \& Kan, 2009), bu politikalar arasında değerlendirilebilir.

$\mathrm{Bu}$ politikalar arasında yer alan $\mathrm{OBB}$, devlet okullarında daha iyi kararlar alınması yönünde vaat veren önemli bir yeniliktir. Okulların kendi amaçlarına ulaşması ve problemlerini zamanında çözebilmesi için, mevcut kaynakların okul özelliklerine ve ihtiyaçlarına göre etkin bir şekilde kullanılmasına hizmet eden bir ortam sağlamaktadır (Yau \& Cheng, 2011). OBB'nin başlangıç noktası, kaynakların okulların ihtiyaçlarına göre belirlenmesi ve tahsis edilmesidir. OBB yoluyla mevcut fonların kullanımı konusunda okulların karar yetkisinin en üst düzeye çıkarılması amaçlanmaktadır. Okullara fonları kullanmak için daha fazla yetki verilirse, daha yenilikçi ve etkili bir kullanım anlayışının oluşacağı varsayılmaktadır ve bu durumun öğrencilerin öğrenme süreçlerine olumlu yönde etkide bulunacağı düşünülmektedir (Levin, 1987). OBB ile karar verme sürecinin okul düzeyinde konumlandırılması, yüksek öğrenci başarısını beraberinde getirecektir (Iatarola \& Stiefel, 1998). Finansal yönetim ile ilgili kararların okullara devredilmesi yoluyla öğrenci performansını olumlu yönde etkileyebilecek daha iyi kararların alınabileceği düşünülmektedir. Okul yöneticileri de dâhil olmak üzere okula daha yakın olan paydaşların, okullarının problemleri ve ihtiyaçları konusunda daha fazla bilgiye sahip oldukları kabul edilmektedir. Dolayısıyla okul paydaşlarına kaynakların yönetimi konusunda karar verme yetkisinin verilmesinin, kaynakların belirlenen hedefler doğrultusunda kullanılmasına yardımcı olacağına inanılmaktadır (Rossmiller, 1997). OBB aracılığıyla aynı zamanda öğretmenlerin kendi okullarında eğitim politikalarının geliştirilmesine ve velilerle daha yakın bir şekilde çalışılmasına yardımcı olmaları beklenmektedir (Moser, 1998). OBB'nin gerek öğretim gerekse yönetim süreçlerinde gözlenen bu tür olumlu etkileri, okul gelişimini sağlamada önemli bir araç olarak kullanılabileceğine işaret etmektedir. Benzer şekilde Goertz (2001), OBB politikalarının, öğrencilere en yakın olan kişilerin bakış açılarını karar verme sürecine dâhil ederek okulların etkinliğini ve verimliliğini artırmayı amaçladığını ileri sürmektedir.

Okul paydaşlarının ve özellikle okul yöneticilerinin okul bütçesinin hazırlanması ve kullanılması süreçlerinde rol alması, okul gelişimi açısından katkı sağlayıcıdır. Ancak ülkemizde taşra teşkilatı, finansman akışını sağlama noktasında görev almakta ve taşra teşkilatının eğitim finansmanı ile ilgili olarak karar verici bir rolü bulunmamaktadır (Eldeniz, 2018). Bu noktada ülkemizde, taşra teşkilatının ve özellikle okul yöneticilerinin ve paydaşlarının bütçeleme süreçlerine katılımı ve okul bütçelerinin 
yapılandırılması konusunda çeşitli araştırmalar yapılmıştır. Özdoğan Özbal (2017), Milli Eğitim Bakanlığı tarafından okullara sağlanan ödeneğin yeterli olmadığını ve harcama prosedürü ile ilgili sıkıntılar yaşandığını belirlemiş ve okulların bütçe yapılanmalarının yeniden yapılandırılması gerektiği sonucuna ulaşmıştır. Hoşgörür ve Arslan (2014), her okula büyüklüğüne ve öğrenci sayısına göre bütçe tahsis edilmesi ve okullardaki komisyonların harcama yetkisine sahip olması gerektiğini tespit etmiştir. Aynı zamanda ödeneklerin okullara zamanında gönderilmesinin de bir ihtiyaç konusu olduğunu saptamıştır. Benzer şekilde Çankaya ve Gün (2016), yöneticilerin okulların bütçe konusunda daha fazla imtiyaz sahibi olmaları ve okul yönetimlerinin kendilerine uygun bütçe planlamasını yapmaları konusunda ortak görüşe sahip olduklarını tespit etmiştir. Bu noktada OBB anlayışı gibi okul temelli anlayışlar bir çözüm yolu olarak ortaya çıkmaktadır. Ancak okul temelli bir anlayışın uygulanmasında, okul yöneticilerinin sahip olması gereken yeterlikler gibi çeşitli faktörlerin dikkate alınarak bir yapılanma sürecine gidilmesi önem taşımaktadır. Nitekim Karakütük ve Özdoğan Özbal (2017), lise müdürlerinin bütçenin planlanması, uygulanması ve bütçeyle ilgili hukuksal düzenlemelere ilişkin sahip oldukları yeterliklerin, sahip olunmasını düşündükleri yeterliklere göre daha az olduğunu saptamıştır. Bu nedenle taşra teşkilatı ile birlikte okul yönetimlerinin bütçeleme sürecindeki rollerini belirleme ve genişletme konusunda yapılacak olan olası çalışmalarda, okul yöneticileri ile ilgili faktörlerin de göz önünde bulundurulması gerekmektedir.

Türkiye'de taşra teşkilatının ve okul yönetimlerinin bütçe yönetim sisteminde daha etkin bir rol sahibi olmasının gerekliliği, üzerinde tartışılan bir konu olmuştur. Onuncu Kalkınma Planı (2014-2018) kapsamında okul yönetimlerinin bütçeleme süreçlerindeki yetki ve sorumluluklarının artırılacağı (Kalkınma Bakanlığı, 2013) ve Milli Eğitim Bakanlığı (MEB) Stratejik Planı (2015-2019) kapsamında ise, OBB sistemine geçileceği (MEB, 2015) ifade edilmiştir. Bu gelişmeleri takiben Temel Eğitim Genel Müdürlüğüne bağlı anaokulu, ilkokul ve ortaokulları kapsayacak şekilde OBB politikası benimsenmiştir. OBB kapsamında "tüketime yönelik mal ve malzeme alımları" giderlerini kapsayan ödeneğin "okul, ilçe ve il bazlı dağılımının" gerçekleştirilmesi planlanmaktadır. Bu süreçte "il/ilçe milli eğitim müdürlükleri ile okul müdürlüklerinin bütçeleme işlemlerinde yetki ve sorumluluklarının artırılması", "kaynakların daha etkin ve verimli kullanımı" ve "okul, ilçe, il ve ülke geneli tüketim miktarları ve istatistiki bilgilerinin sağlıklı bir şekilde elde edilmesi” amaçlanmaktadır (MEB Temel Eğitim Genel Müdürlüğü, 2017, s.1). OBB uygulamasında; Temel Eğitim Genel Müdürlüğünün, il ve ilçe milli eğitim müdürlüklerinin ve okul müdürlüklerinin yetki ve sorumlulukları bulunmaktadır. OBB kapsamında "Genel Müdürlükçe gönderilen ödeneklerin harcama yetkilisi kendisine ödenek tahsis edilen büyükşehir kapsamında olmayan il milli eğitim müdürlükleri ile ilçe milli eğitim müdürlükleri” olarak ifade edilmiştir. Dolayısıyla harcama yetkisi ile birlikte Genel Müdürlük tarafindan belirlenen ödenekleri okul bazında inceleme ve gerekli durumlarda toplam ödenek miktarında değişim olmaksızın okul bütçelerinde değişiklik yapma sorumlulukları ilçe milli eğitim müdürlüklerine aittir (MEB Temel Eğitim Genel Müdürlüğü, 2017, s.2).

OBB'de okul müdürlüklerinin görev, yetki ve sorumlulukları ise şu şekilde belirtilmiştir (MEB Temel Eğitim Genel Müdürlüğ̈̈, 2017): 
- Okula ait her türlü bilginin e-Okul ve MEİS Modülüne doğru ve zamanında girişini sağlamak ve onaylamak,

- Genel müdürlükçe okul için hesaplanan ve il/ilçe milli eğitim müdürlüğünce güncellenerek MEBBİS Temel Eğitim Ödenek İşlemleri Modülündeki Kurum Ödenek Bilgileri ekranında ilan edilen bütçe ve varsa okulun aile birliği gelirleri birlikte değerlendirilerek yıllık okul ihtiyaçlarının planlamasını yapmak, ihtiyaç listesini il/ilçe milli eğitim müdürlüğüne bildirmek, Ödenek miktarları dikkate alınarak gerekli tasarruf tedbirlerini uygulamak,

- İl/ilçe milli eğitim müdürlükleri tarafindan okul için yapılan her türlü harcama bedelini, Kurum Ödenek Bilgileri ekranındaki ilgili tabloya işlemek,

- Mevcut ödenek miktarları ile karşılanamayacak olan giderlerini ve gerekçesini il/ilçe milli eğitim müdürlüklerine bildirmek. (s.3).

Her ne kadar ülkemizde OBB politikasının uygulanması yönünde adımlar atılsa da, mevcut uygulamanın tam anlamıyla OBB politikasının özelliklerini yansıtmadığı da görülmektedir. Okul tabanlı finansal yönetim (Baines, 2007; Tooley \& Guthrie, 2003) olarak da adlandırılan OBB, karar verme sorumluluklarının merkezi yönetimden alınarak okul müdürlerine, öğretmenlere ve toplum fertlerine kaydırıldığı okul tabanlı yönetimin bir alt koludur (Wohlstetter \& Van Kirk, 1995). OBB, okul temelli yönetimi kolaylaştırmaktadır (Hadderman, 2002). Okul temelli yönetim bağlamında okulların otorite açısından en kritik rolü, bütçe yetkilisi olmalarıdır (Briggs \& Wohlstetter, 2003). Okul temelli yönetimin en önemli özelliği ise, okulları kendi bütçelerini yönetme ve tahsis etme konusunda güçlendirmektir (Hsieh \& Hsieh, 2005). OBB kapsamında okullarda yöneticiler, öğretmenler ve velilerden oluşan planlama ekipleri kurularak okul temelli bütçeler hazırlanmaktadır. Bu planlama ekiplerinin başlıca sorumluluğu, okulun önceliklerini belirlemek ve uzun vadeli planlar geliştirmektir (Moser, 1998). Elbette OBB'nin ülkemizde merkezi yönetim anlayışılla bütünleştirilerek uygulanması, OBB'nin temel karakteristik özelliklerinin mevcut uygulamada yer almamasına neden olmakta ve OBB politikasının eğitim sistemimizin özelliklerine uygun bir biçimde farklılaştırılmasını gerektirmektedir.

OBB'nin okul gelişimi açısından istenen sonuçları verebilecek şekilde farklılaştırılarak başarıyla uygulanabilmesi için dikkat edilmesi gereken önemli hususlar bulunmaktadır. OBB'nin uygulanma süreci zor ve zaman alıcıdır. Uygun karar vericilerin belirlenmesi, sahada verilecek kararların kapsamı, personel eğitimi, hesap verebilirlik, kaynak dağılımı, uygulama kaynakları ve zaman çizelgeleri göz önünde bulundurulması gereken önemli konulardır. Bu süreçte nakit akışını, risk yönetimini, farklı öğrenci ihtiyaçlarını ve çeşitli okul özelliklerini ele almak için pratik stratejiler geliştirilmelidir (Picus, 1997). Merkezi yönetimin; personelin rollerini tanımlaması ve sınırlandırması, hizmet içi eğitim sağlaması, envanter paylaşımını teşvik etmesi ve kaynak yönetimini değerlendirmesi gerekmektedir (Polansky, 1998). Goertz (2001) tarafından yapılan araştırma, OBB uygulamasının; gerçekçi olmayan bütçe teslim tarihleri, okul ve merkezi yönetim arasındaki iletişim sorunları ve bütçeleme konusundaki yetersiz bilgi ve eğitim nedeniyle etkili bir şekilde yürütülmediğini göstermiştir. Bu nedenle OBB'ye ilişkin geliştirilen politikaların okul gelişimine hizmet edebilmesi için doğru ve etkili bir şekilde planlama yapılması, okulların farklı ihtiyaçlarının dikkate alınması ve aktif bir bilgilendirme ve iletişim ağı oluşturulması oldukça önemlidir.

Temel Eğitim Genel Müdürlüğüne bağlı kurumlarda OBB uygulamas1, okul yöneticilerine tam anlamıyla okul tabanlı finansal bir yönetim yetkisi vermemesine rağmen, okul yönetimlerine bütçeleme sürecinde aktif bir rol vermesi ve bu şekilde okul 
ihtiyaçlarının daha etkili bir şekilde karşılanmasının sağlanması bakımından önemli bir gelişmedir. OBB'nin alan yazında okul gelişimine yönelik belirtilen katkıları dikkate alındığında, ülkemizde OBB'nin okul gelişimine ne yönde bir fayda sağlayabileceğinin incelenmesinin önem taşıdığ 1 anlaşılmaktadır. Aynı zamanda OBB'ye ilişkin başarı faktörlerinin bulunması, OBB'nin okul gelişimindeki rolünü güçlendirebilmek için mevcut uygulamada yapılması gereken değişikliklerin ve yeniliklerin incelenmesinin gerekliliğine işaret etmektedir. OBB politikasının diğer ülke örneklerine göre ülkemizde farklı bir şekilde yapılandırıldığı düşünüldüğünde, eğitim sistemimizin ve okullarımızın bağlamsal özellikleri doğrultusunda uygulama sürecinin sürekli değerlendirilmesi ve özellikle okulların farklı ihtiyaçlarının dikkate alınması gerektiği söylenebilir. Bu noktada okulların ihtiyaçlarını en iyi bilen kişiler olmaları ve söz konusu uygulamada sahip oldukları önemli rol bakımından, OBB uygulamasının okul yöneticilerinin görüşleri doğrultusunda değerlendirilmesinin, OBB'nin eğitim sisteminde istenen çıtıları sağlamasına katkıda bulunabileceği düşünülmektedir.

\section{Araştırmanın Amacı ve Problemleri}

$\mathrm{Bu}$ araştırmada; okul yöneticilerinin OBB uygulamasına ve OBB'nin okul gelişimine nasıl katkı sağlayabileceğine ilişkin görüşlerinin incelenmesi amaçlanmıştır. $\mathrm{Bu}$ amaç doğrultusunda aşağıdaki sorulara yanıt aranmıştır:

1. Okul yöneticilerinin mevcut OBB uygulamasına ilişkin görüşleri nelerdir?

2. Okul yöneticileri, OBB'nin okul gelişimine yönelik katkılarının neler olabileceğini düşünmektedirler?

\section{Yöntem}

Nitel araştırma yöntem ve tekniklerinin kullanıldığı araştırma, betimleyici yaklaşımla gerçekleştirilmiştir. Teorik bir çerçeve tarafından sınırlandırılmayan betimleyici nitel araştırmalarda, bireylerin veya grupların belirli konulardaki deneyimleri doğal araştırma yaklaşımının kullanılmasıyla kapsamlı bir şekilde incelenir (Lambert \& Lambert, 2012). Betimleyici araştırmalarda, araştırma konusu veya bir politika sorunu ile ilgili bir şekilde ihtiyaçlar, uygulamalar ve politikalar hakkında bilinenler ortaya konulur (Loeb ve diğerleri, 2017). Bu araştırmada da bir finansman politikası olarak OBB, uygulanmaya başladığı ilkokul ve ortaokullarda tamamen okul yöneticilerinin deneyimleri doğrultusunda incelenmiş ve tamamen okul yöneticilerinin görüşlerine dayalı olarak okul geliştirme işlevi açısından değerlendirilmiştir.

\section{Çalışma Grubu ve Özellikleri}

Araştırmanın çalışma grubu, Gaziantep ilinde görev yapan 29 ilkokul ve ortaokul yöneticisinden oluşmaktadır. Katılımcılar, maksimum çeşitlilik örneklemesi yoluyla belirlenmiştir. Maksimum çeşitlilik örneklemesinde, örneklemin oluşturulması amacıyla öncelikle farklı özellikler veya kriterler belirlenir. Bu şekilde çeşitlilik gösteren bir örneklemin seçilmesi sonucunda, ortaya çıkan bu çeşitlilikten anlam kazanan önemli ortak yapılar belirlenebilir (Patton, 1990). Bu araştırmada, çeşitlilik sağlanan özellikler; görev yapılan kademe ve yöneticilik pozisyonu olarak belirlenmiştir. Görev yaptıkları kademe ve bulundukları yönetim pozisyonu açısından farklılaşan bir çalışma grubunun oluşturulmasıyla OBB'ye ilişkin daha bütüncül bir anlayış elde edilmesi amaçlanmıştır. 
Araştırmanın katılımcılarının; 15'i ilkokul yöneticisi ve 14'ü ortaokul yöneticisidir. Okul yöneticilerinin 12'si okul müdürü, 17'si ise, müdür yardımcısıdır. Katılımcıların 22'si erkek, 7'si kadındır. Öğretmenlik mesleğindeki kıdemleri 7 yıl ile 30 yıl; yöneticilikteki kıdemleri ise, 1 yıl ile 20 yıl arasında değişmektedir.

\section{Veri Toplama Aracı ve Verilerin Toplanması}

Araştırma verileri, yarı yapılandırılmış görüşmeler ve odak grup görüşmeleri aracılığıyla toplanmıştır. 15 okul yöneticisi ile yarı yapılandırılmış görüşme ve 14 okul yöneticisi ile iki odak grup görüşmesi oturumu yapılmıştır. Yarı yapılandırılmış görüşmelerin süresi toplam 302 dakikadır. Odak grup görüşmelerinin süreleri ise; 98 ve 104 dakikadir.

Yarı yapılandırılmış görüşmelerde ve odak grup görüşmelerinde aynı sorular kullanılmıştır. Görüşme soruları hazırlandıktan sonra ikisi yarı yapılandırılmış ve biri odak grup görüşmesi olmak üzere 3 pilot görüşme gerçekleştirilmiştir. Pilot görüşmelerde soruların anlaşılırlığında ve kapsamında herhangi bir sorun yaşanmadığı gözlenmiştir. Bu nedenle görüşme sorularında herhangi bir değişiklik yapılmamış ve pilot görüşmelerden elde edilen veriler, analiz edilen veri setine dâhil edilmiştir. Yarı yapılandırılmış görüşmelerde ve odak grup görüşmelerinde kullanılan sorular şunlardır:

1. OBB uygulamasının okulların bütçeleme konusundaki yetki ve sorumluluklarını artırdığını düşünüyor musunuz?

1.1. Hangi konularda yetki ve sorumluluk artışı olduğunu düşünüyorsunuz?

1.2. Yetki ve sorumluluk artış1, okul yönetiminin performansını nasıl etkilemektedir? Yetki ve sorumluluk artışı, okul yönetiminin diğer sorumluluk alanlarına nasıl yansımaktadır?

2. OBB'nin kaynakların daha etkili ve verimli kullanılmasını sağlayacağını düşünüyor musunuz? Bu konudaki görüşlerinizi açıklar mısınız?

3. MEBBİS (Milli Eğitim Bakanlığı Bilişim Sistemleri) ödenek takip modülünü kullanmada ne tür zorluklar yaşıyorsunuz? Modülü işlevsel buluyor musunuz?

3.1. Modülün hangi konularda size yardımcı olduğunu düşünüyorsunuz?

3.2. Modülün daha etkili kullanımı için neler yapılabilir?

4. Genel müdürlük tarafından okul bazlı hazırlanan ve il/ilçe milli eğitim müdürlükleri tarafından güncellenen ödenek miktarlarını yeterli buluyor musunuz? Bu konudaki görüşlerinizi açıklar mısınız?

4.1. Bütçeye okul özelliklerinin tam olarak yansıtıldığını düşünüyor musunuz? Bu konudaki görüşlerinizi açıklar mısınız?

4.2. Ödenek miktarlarının hazırlanmasında ve güncellenmesinde okullara ait hangi ölçütler dikkate alınmalıdır?

5. OBB uygulamasının daha etkili bir şekilde yürütülebilmesi için neler yapılması gerektiğini düşünüyorsunuz? Bu konudaki önerileriniz nelerdir?

6. OBB uygulamasının okullarda nasıl bir gelişim sağlayacağını düşünüyorsunuz?

6.1. Okul yönetimi süreçleri açısından nasıl bir gelişim gözlenebilir?

6.2. Öğretim süreçlerinin niteliği açısından nasıl bir gelişim gözlenebilir?

C) 2019 AKU, Kuramsal Eğitimbilim Dergisi - Journal of Theoretical Educational Science, 12(2), 727-756 
6.3. Okulun sosyal ve fiziki donanımı açısından nasıl bir gelişim gözlenebilir?

6.4. Okul-çevre ilişkileri açısından nasıl bir gelişim gözlenebilir?

Görüşmelerde okul yöneticilerine; OY-1 (Okul Yöneticisi-1), OY-2 (Okul Yöneticisi-2) şeklinde kodlar verilmiştir. Görüşmelerin kaydedilmesine izin veren yöneticilerle yapılan görüşmeler, ses kayıt cihazı ile kaydedilmiş; kayıt yapılmasını istemeyen okul yöneticileri ile yapılan görüşmeler ise, yazılı olarak not edilmiştir. Toplanan verilerin tamamı, analiz edilmek üzere yazıya aktarılmıştır.

\section{Verilerin Analizi}

Görüşmelerden elde edilen veriler, içerik analizi ile çözümlenmiştir. İçerik analizi; tema, alt tema ve kavram düzeylerinde gerçekleştirilmiştir. "OBB uygulamasının okul yönetiminin yetki ve sorumlulukları üzerindeki yansımaları”, "OBB uygulaması kapsamında MEBBİS ödenek takip modülünün kullanımı”, “OBB kapsamında okul bütçesi oluşturma süreci”, “OBB uygulamasının okul gelişimine katkıları" ve "okul geliştirme işlevi açısından OBB uygulamasının geliştirilmesine yönelik öneriler" olmak üzere beş ana tema oluşturulmuştur. Temalar ve alt temalar, görüşme soruları doğrultusunda; kavramlar ise, araştırma verilerine dayalı olarak belirlenmiştir. Birinci, ikinci, üçüncü ve dördüncü temaya bağlı kodlamalar alt tema ve kavram düzeyinde gerçekleştirilirken; beşinci temaya bağlı kodlamalar ise, sadece kavram düzeyinde gerçekleştirilmiştir.

\section{Araştırmanın Geçerlik ve Güvenirliği}

Araştırmanın geçerliğinin sağlanmasına yönelik çalışmalar kapsamında; okul yöneticileri ile yapılan yarı yapılandırılmış görüşmelerde ve odak grup görüşmelerinde, uzun süreli etkileşim sağlanmasına (Manning, 1997) önem verilmiştir. Bu şekilde hem görüşmeler süresince okul yöneticileri ile etkili bir iletişim kurulmuş hem de okul yöneticilerinin OBB'yi doğru ve kapsamlı bir şekilde değerlendirmeleri sağlanmıştır. Görüşmeler süresince araştırmacılar tarafından yapılan çıkarımlar, okul yöneticilerine aktarılmış ve aynı zamanda analiz sürecinin sonucunda ortaya çıkan bulgular, katılımcılar arasında yer alan 5 okul yöneticisine bildirilmiştir. Bu şekilde katılımcı teyidine (Creswell, 2002) başvurularak ulaşılan bulguların katılımcıların görüşlerini yansıttığına dair onay alınmıştır. Bulguların sunumunda, katılımcı ifadelerinden doğrudan alıntılara (Sandelowski, 1986) yer verilerek bulgular doğrultusunda yapılan yorumlara netlik kazandırılmıştır. Araştırmada amaçlı örnekleme yöntemlerinden maksimum çeşitlilik örneklemesi kullanılarak katılımcıların seçiminde benimsenen anlayışa ve katılımcılara bağlı olarak araştırma süreçlerini etkileyebilecek faktörlere netlik (Leininger, 1994) kazandırılmıştır.

Araştırmanın güvenirliğinin sağlanmasına yönelik çalışmalar kapsamında; görüşmelerde okul yöneticilerinin OBB uygulamasında gözlemleyebilecekleri konulara ilişkin sorular sorulmuş ve böylece görüşme sorularının düşük seviyede çıkarıma (Field \& Morse, 1985; Richards \& Schmidt, 2002) yönelik olması sağlanmıştır. Görüşme sorularının bu niteliği, okul yöneticilerinden toplanan verilerin tutarlık göstermesini de sağlamıştır. Eğitim yönetimi alanında bir uzmana araştırmanın süreçleri hakkında bilgi verilerek toplanan ham verileri, kodlamaları ve ulaşılan sonuçları tutarlık açısından incelemesi istenmiştir. Bu şekilde kullanılan yöntemlerin ve araştırma süreçlerinde benimsenen anlayışın tutarlı olduğu yönünde uzman görüşü (Morrow, 2005) alınmıştır. 
Araştırmada ulaşılan bulguların bütünlük içinde olduğuna ve bulgular ile yapılan yorumların bağlantılı olduğuna yönelik teyit almak için denetleme yolu (audit trail) ile uzman görüşüne başvurulmuştur. Bu süreçte; ham veriler, analiz ve yorumlamalar ve bulgular olmak üzere üç aşamalı bir inceleme (Wolf, 2003) gerçekleştirilmiştir.

\section{Bulgular}

\section{OBB Uygulamasının Okul Yönetiminin Yetki ve Sorumlulukları Üzerindeki Yansımalarına İlişkin Bulgular}

Okul yöneticilerinin, OBB uygulamasının yetki ve sorumlulukları üzerindeki yansımalarına yönelik görüşleri, Tablo 1 'de yer almaktadır.

Tablo 1

OBB Uygulamasının Okul Yönetiminin Yetki ve Sorumlulukları Üzerindeki Yansımaları Temasına Bă̆glı Kodlamalar

\begin{tabular}{|c|c|}
\hline $\begin{array}{l}\text { Alt Tema 1: Okul Yönetiminin Yetki ve } \\
\text { Sorumluluklarındaki Değişim }\end{array}$ & $\begin{array}{c}\text { Alt Tema 2: OBB Kapsamındaki Yetki ve } \\
\text { Sorumlulukların Okul Yönetiminin Performansına } \\
\text { Etkisi }\end{array}$ \\
\hline 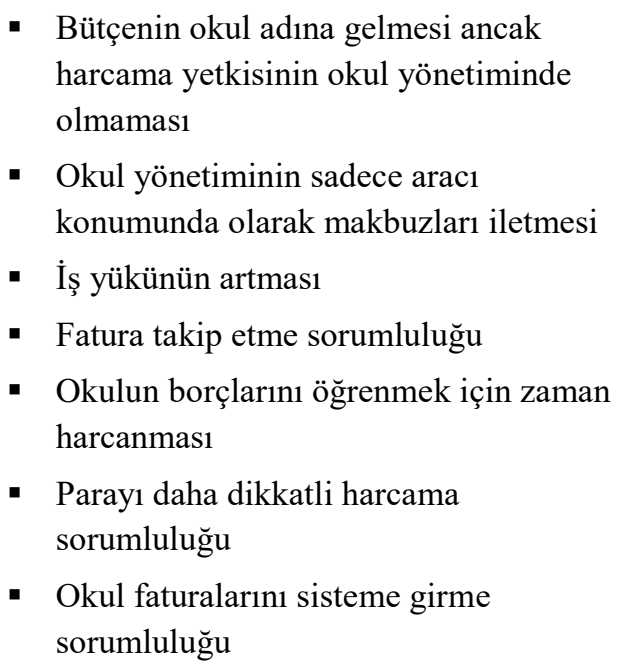 & $\begin{array}{l}\text { - Sorumluluk artışının tedirgin etmesi } \\
\text { - Faturaları takip etme kolaylığının zaman } \\
\text { tasarrufu sağlaması } \\
\text { - Evrak işinin azalmasının zaman yönetimine } \\
\text { destek olması } \\
\text { - Okul bütçesinin ihtiyaçlar doğrultusunda } \\
\text { harcanmasının yönetim performansını artırması } \\
\text { - Faturalarla ilgili işlemlerin zaman kaybına } \\
\text { neden olması } \\
\text { - Veliler ile olan ilişkilerin düzelmesinin yönetim } \\
\text { performansını artırması }\end{array}$ \\
\hline
\end{tabular}

Okul yöneticilerinin tamamı, OBB uygulaması kapsamında yetkilerinde henüz bir değişim olmadığını ifade etmiştir. Bir bölümü, sorumluluklarında artış şeklinde bir değişim olduğunu düşünürken; diğer bölümü ise, sorumluluklarında da bir değişim olmadığını düşünmektedir. Okul yöneticilerinin sorumluluklarına ilişkin görüşlerindeki bu farklılık, OBB kapsamındaki yetki ve sorumluluklarının yönetimsel performanslarına yansımasının da gerek olumlu gerekse olumsuz yönde değerlendirilmesine neden olmuştur.

OBB'de herhangi bir yetkisi olmadığını düşünen okul yöneticileri, kendilerinin sadece okula ait faturaların iletilmesinde aracı olduklarını belirtmişlerdir. Aynı zamanda bütçenin okul adına belirlendiğini ancak kendilerinin harcama yetkisi olmadığını vurgulamışlardır. $\mathrm{Bu}$ yönde görüş sahibi olan OY12; "Bizim faturalara yönelik bildirimlerimizle bütçe belirleniyor ama milli eğitim, bütçeyi bizim yerimize kullanıyor. Biz şu an aracı konumundayız. Gelen makbuzları gönderiyoruz. Şu an, en azından kaynakların kullanımını nasıl gerçekleştirdiğimizi biliyoruz." açıklamasını yapmıştır. 
OY4 ise, şu an bir geçiş süreci yaşandığının altını çizerek yetki ve sorumluluklarına ilişkin; "Bu bir geçiş süreci. Önce ilçelerden harcamalarla ilgili veriler topland. Desimal dosyalarımızda geçmiş yılların faturaları var. Bu faturaları inceledik ve son beş yılın faturalarının ortalamasını alarak sisteme giriş yaptık. Ama zamanla bütçeler yerine oturduğunda, yetki ve sorumluluklarımızın artacağını düşünüyorum." ş̧eklinde görüş bildirmiştir.

Sorumluluklarının arttığını ve değiştiğini düşünen okul yöneticileri, artan sorumluluklarının daha çok fatura işlemleri ile ilgili olduğunu ifade etmişlerdir. Fatura takip etme sorumluluğu, okulun faturalarını sisteme girme sorumluluğu ve okulun borçlarını öğrenmek için zaman harcanması bu kapsamda değerlendirilmiştir. OY7, OBB uygulamasında sisteme doğru veri girebilmek için okulun borçlarını araştırdıklarını şu şekilde anlatmıştır: "TEDAŞ’a gidip okulun borcu var mı diye sorduk. Bizim kuruş olarak borcumuz varmış ve ödenmediği için faiz binmiş ve daha büyük bir miktar oluşmuş. Faturalarımızla ilgili doğru rakamı verebilmek için bu konuyu araştırdık mesela." Okul yöneticileri, faturaların zamanında ödenebilmesi ve faiz ödeme durumunda kalınmaması için, okulun borçlarını öğrenme yükümlülükleri olduğunu vurgulamışlardır. Bu şekilde borç sorgulama yönünde çaba sarf edilmesini ise, zaman kaybı olarak nitelendirmiş ve bu durumun, yönetim performansında düşüşe neden olabileceğini belirtmişlerdir. Bu konuda OY6, özellikle köylerde çalışan okul yöneticileri açısından yaşanabilecek sıkıntıyı; "Her ay kurumları dolaşıp 'okulun borcu var mı?' diye soracakmışım. Merkezde olanlar (okul yöneticileri) tamam da, köydekiler ne yapsın? Okulun işlerine nasıl vakit ayırsın? Sorumluluklar artarken bir takım şeyler de artmalı. Sorumluluk ve iş gücü artıyor ama bir getirisi yok.” diyerek açıklamıştır.

Uygulamayı zaman kaybı olarak nitelendiren yöneticilerin yanı sıra zaman açısından tasarruf sağladığını düşünenler de bulunmaktadır. Bu yönde düşünen $\mathrm{OY} 2$; "Okul bazlı bütçelemeyle zamandan tasarruf ettik. Git-gel yapma, evrak işi kalktı. Her şeyi sistemden otomatik olarak yapabiliyoruz." diyerek fatura işlemlerinin sistem üzerinden yapılmasına yönelik memnuniyetini belirtmiştir. Okul yöneticileri arasında, faturaların sisteme girilmesi ve takip edilmesi yönündeki sorumlulukların kendisini tedirgin ettiğini belirtenler olmuştur. OY1, OBB kapsamında faturaları zamanında sisteme girme sorumluluğu olduğunu ve bu konuda gecikme yapma ihtimalinin kendisini rahatsız ettiğini; "Bütçelemede bizim yetkimiz yok ama sorumluluklarımız var. Ödenekleri sadece sistemde görebiliyoruz. Önceden faturalart ilçe MEB'e elden teslim ediyorduk. Şimdi sisteme işliyoruz. Sorumluluk artışı, bizi tedirgin ediyor. Fatura gecikirse faizini okul idaresinden istiyorlar." şeklinde dile getirmiştir.

Okul yöneticileri, okul bütçesinin ihtiyaçlar doğrultusunda harcanmasının yönetim performansını artıracağını belirtmişlerdir ancak bunun için uygulamanın mevcut halinin geliştirilmesi gerektiğine dikkat çekmişlerdir. OBB'nin bütçe oluşturma süreci açısından geliştirilmesine bağlı olarak yönetsel performansını da geliştireceğini düşünen OY9, şu şekilde görüşlerini paylaşmıştır: "Okulun ihtiyaçlarını içeren bir bütçe oluşturulduğunda, ben de sadece okulun işlerine odaklanırım. Eksik kapatmak için kafa yorup enerjimi tüketmem. Uygulamanın şimdiki halinde sadece su, doğalgaz ve elektrik faturalarını bildiriyoruz ve buna göre bir bütçe oluşturuluyor. Ama ileride tüm ihtiyaçlar kapsanırsa ben de daha verimli çalışabilirim." OBB'nin bütçe oluşturma süreci açısından geliştirilmesine bağlı olarak okul yönetimi performansında ileride pozitif etki oluşturacağı düşünülen bir diğer konu, veliler ile olan ilişkilerin 
düzeleceğine yöneliktir. Okul yöneticileri, bazı velilerin okula ihtiyaçlar için para isteneceği endişesi yüzünden gelmediğini ve bu durumun da okul-aile ilişkilerine zarar verdiğini belirtmişlerdir. Bu konuyla ilgili olarak OY22; "Bütçemizi ihtiyaçlarımıza göre belirleme yetkimiz olduğunda ve bütçe yeterli olduğunda, okulumuzun her türlü ihtiyacını rahatlıkla karşılayabiliriz. Okul-aile birliği çalışmalarında, velilerle para konusunda sorun yaşıyoruz çoğu zaman. İhtiyacımıza göre bütçemiz olursa, veliler okula daha rahat gelir. Biz para istemesek bile veli talepte bulunacă̆ı diye okula gelmiyor. 'Okula gidersek bizden para toplayacaklar' algisı ortadan kalkar.” şeklinde görüşlerini ifade etmiş ve velilerle olan sağlıklı ilişkilerin yönetsel performansa olumlu yönde etkide bulunacağını belirtmiştir.

\section{OBB Uygulaması Kapsamında MEBBİS Ödenek Takip Modülünün Kullanımına İlişkin Bulgular}

Okul yöneticilerinin, OBB uygulaması kapsamında MEBBİS ödenek takip modülünün kullanımına ilişkin görüşleri, Tablo 2'de sunulmuştur.

Tablo 2

OBB Uygulaması Kapsamında MEBBİS Ödenek Takip Modülünün Kullanımı Temasına Bağlı Kodlamalar

Alt Tema 1: MEBBİS Ödenek Takip

Alt Tema 2: MEBBİS ÖTM'nin Geliştirilmesi Modülünün İşlevselliği

- Fatura takibinde yardımcı olması

- Fatura yüklemede boyut sorununun olmas1

- Okulun internet bağlantısının zayıflığının kullanımı zorlaştırması

- MEBBİS'deki diğer modüllerle (yardımcı hizmetler modülü gibi) uyumlu bir şekilde kullanılabilmesi

- Artan bütçenin sistemde başka kalemlere aktarımının sağlanmasının gerekliliği
- Kullanım açısından sadeleştirilmeli

- Kullanımı konusunda hizmet içi eğitim verilmeli

- Okula ait faturalar otomatik olarak sisteme yansimalı

- Okula ait sorunlar sistem üzerinde ayrıca belirtilebilmeli

- Aynı tür verilerin girildiği sistemlerle (e-okul, MEİS, okul yönetim sistemi) birleştirilmeli

- Ödeneğin yeterliliğinin anlaşılabilmesi için TEFBİS (Türkiye'de Eğitimin Finansmanı ve Eğitim Harcamaları Bilgi Yönetim Sistemi) ve MEBBİS birleştirilmeli

Okul yöneticileri, MEBBİS ödenek takip modülünü genel olarak kullanışlı bulmakta ve faturaların takibi açısından işlevsel olduğunu düşünmektedirler. OY28; "Takip modülünü kullanırken herhangi bir sorun olmuyor. Faturaların hangi aşamada olduğunu takip edebiliyoruz." diyerek takip kolaylı̆̆ına dikkat çekerken, OY16 ise; "Modülde sıkıntı yok kullanım olarak. Faturaları karşılaştırabiliyoruz. Tasarruf edip etmediğimizi görebiliyoruz." sözleriyle sistemin OBB'nin tasarruf sağlama amacina yardımcı olduğuna vurgu yapmıştır. MEBBİS'deki modüllerin uyumlu bir şekilde kullanılabilmesi, okul yöneticilerinin belirttiği bir diğer olumlu özelliktir. Okul yöneticileri, farklı modüllerin MEBBİS kapsamında yer almasıyla sistemin çok boyutlu hale geldiğini düşünmektedirler. $\mathrm{Bu}$ şekilde her ne kadar bütün modüller şu anda kullanılamasa da, ileride daha fazla ihtiyaca cevap verilebileceğini ifade etmişlerdir. OY25, MEBBİS'in çok boyutlu olmasını olumlu yönde değerlendirerek şu şekilde 
görüşlerini paylaşmıştır: "Modülü faydalı buluyorum ve kullanımı kolay. Modülün içinde fiziki koşullarla, donanımla ilgili verileri girdiğimiz MEİS var. Aynı zamanda etalep üzerinden taleplerimizi belirtebiliyoruz. Tabii hepsi aktif bir şekilde kullanılmıyor mevcut durumda. Ama hepsi uyumlu bir şekilde MEBBIS üzerinden kullanılabilecek şekilde." Okul yöneticileri arasında, okulun artan bütçesinin farklı harcama kalemlerine aktarılması gerektiğini ve bunun da ileride, MEBBİS'deki farklı modüllerin kullanımı ile sistem üzerinden yapılabileceğini düşünenler bulunmaktadır. Bu yönde düşünen okul yöneticileri, MEBBİS'i bu açıdan mevcut haliyle işlevsiz bulmaktadırlar. $\mathrm{Bu}$ yönde düşünen OY14; “OBB'nin faydall olabilmesi için okullar artan bütçelerini kullanabilmeli. (Artan bütçelerini) farklı ihtiyaçlarına aktarabilmeli. Zaten MEBBIS'de farklı modüller var. Şu an bunu yapamıyoruz ama bir kalemde bitmeyen bir parayı başka bir kaleme sistem üzerinde aktarabilmeliyiz." açıklamasını yapmıştır.

Okul yöneticilerinin MEBBİS'e dair eleştiride bulundukları konular; fatura yüklemede boyut sorununun olması ve zayıf internet bağlantısından dolayı verimli kullanılamamasıdır. OY5; "Takip modülünde pek bir sıkıntı yok. Sadece fatura boyutunda sıkıntı oluyor. Sistem kendisi boyutlandırsa daha iyi olur." şeklinde bir öneride bulunmuştur. Ancak OY11 ise; "Modülde boyut sorunu oldu, onu da deneyerek çözdüm. ” diyerek sorunun bireysel olarak çözülebildiğini ifade etmiştir.

Okul yöneticileri, ödenek takip modülünün geliştirilmesi için öncelikle okul yöneticilerine etkili hizmet içi eğitimler verilmesi gerektiğini belirtmişlerdir. Modülün gelişiminin, etkili kullanıma bağl1 olduğunu düşünmektedirler. OY22; "Modüle veri giremeyecek arkadaşlar var. Aslında modülün kullanım kılavuzu var. Ama birçok kişi okumak yerine hazır bilgi istiyor." diyerek modülün kullanımı konusundaki eğitim ihtiyacına işaret etmiştir. OY19 ise; "Kılavuzla ilgili sene başında kalabalık bir gruba eğitim verilmişti ama çok verimli olmadl. Okul yöneticileri, ilçe düzeyinde küçük gruplara ayrllarak belirli zamanlarda eğitim alırlarsa kalite artar." açıklamasını yapmış ve hizmet içi eğitimlerin niteliğine ilişkin görüş bildirmiştir.

Okul yöneticileri arasında, okula ayrılan ödeneğin yeterliliğinin anlaşılabilmesi için TEFBİS VE MEBBİS sistemlerinin birleştirilmesi gerektiğini düşünenler bulunmaktadır. OY7, bu sistemler hakkında bilgi vererek görüşlerini şu şekilde paylaşmıştır:

Bu modülden önce TEFBİS vard. Gelir ve giderlerimizi giriyoruz TEFBİS'e. Bağı̧̧lar, kantin geliri, okul-aile birliği gelirleri gibi okula ait gelirleri ve okulun temizlik ve kırtasiye gibi kendi harcamalarını giriyoruz. MEBBİS'de ödenek takip modülüne; doğalgaz, su ve elektrik faturalarını girebiliyoruz. TEFBİS, mal müdürlügünün bünyesinde; MEBBİS, milli eğitim müdürlüğünün bünyesinde. Ödeneğin yeterli olduğuna karar vermek için ikisi birleşmeli.

$\mathrm{Bu}$ iki sistemin birleştirilmesi yönünde görüş sahibi olan OY3 ise, bu görüşünün gerekçesini şu şekilde açıklamıştır: "Örneğin; elektrik, su ve doğalgaz harcamaları olarak bizim okulun bütçesi 58.000 TL. Ama bu bütçenin içinde yardımcı hizmetler, temizlik, kırtasiye ve donanım gibi kalemler yok. Bu yüzden tek bir sisteme bakarak bütçe yeterli veya yetersiz diyemezsiniz."

Ödenek takip modülüne girilen bilgiler ile benzer bilgilerin girildiği e-okul, MEİS ve okul yönetim sistemi gibi uygulamaların da birleştirilmesinin, uygulamada kolaylık sağlayacağı okul yöneticileri tarafından belirtilmiştir. OY15, Gaziantep iline özgü bir uygulama olduğunu belirttiği okul yönetim sistemine ilişkin; "Şu anda aktif olarak okul yönetim sistemi kullanılıyor. Şehitkamil ilçesi kullanılıyor bu uygulamayı. 
Mesela derslik sayısını sisteme yanlışlıkla fazla girmiştik. Hemen ilçe milli eğitimden telefon açıp durumu sordular." şeklinde bilgi vermiştir. OY24 ise, okul yönetim sistemine ve ödenek takip modülüne benzer verileri girdiklerini ve zamandan tasarruf açısından bu sistemlerin teke düşürülmesi gerektiğini şu şekilde ifade etmiştir: "MEIS'e, e-okula, okul yönetim sistemine sürekli veri giriyoruz. Bunlar tek bir çatı altında birleşirse bizim açımızdan rahatlık olur. Aynı zamanda bütçelerin takibi de daha kolay yapılabilir. Eksikler ve fazlalıklar daha kolay anlaşılabilir ayrıntılı tek bir sistem üzerinden."

\section{OBB Kapsamında Okul Bütçesi Oluşturma Sürecine İlişkin Bulgular}

Okul yöneticilerinin, OBB kapsamında okul bütçesi oluşturma sürecine ilişkin görüşleri Tablo 3 'te gösterilmiştir.

Tablo 3

OBB Kapsamında Okul Bütçesi Oluşturma Süreci Temasına Bağlı Kodlamalar

\begin{tabular}{ll}
\hline \multicolumn{2}{c}{ Alt Tema: Okul Bütçesi Oluşturmada Dikkat Edilmesi Gereken Hususlar } \\
\hline - Okulun bulunduğu bölge dikkate alınmalı & - Okuldaki öğrenci ve personel sayısı dikkate \\
- Kırtasiye ve temizlik malzemeleri için ayrı & alınmalı \\
ödenek olmalı & - Okulun hesabında her zaman kullanıma hazır \\
- Sosyal faaliyetler için ayrı ödenek olmalı & para olmalı \\
- Tamirat ve onarım için ayrı ödenek olmalı & - Projeler için ayrı ödenek olmalı \\
- Okul-aile birliği ve kantin bütçeleri dikkate & - Çok yönlü harcamaya göre bütçe oluşturulmalı \\
- Alınmalı & - Geçmiş yılın bütçesi dikkate alınmalı \\
& - Evrak üzerinde değil sahaya inerek gerçekçi bir \\
& şekilde bütçe oluşturulmalı
\end{tabular}

Okul yöneticileri, OBB uygulamasının mevcut halinde aslında tam olarak bir okul bütçesi oluşturulmadığını belirtmişlerdir. Su, doğalgaz ve elektrik faturalarının ilçe milli eğitim müdürlüğüne bildirimini yaptıklarını ve bu doğrultuda okullar için buna göre ödenek oluşturulduğunu ifade etmişlerdir. Kendilerinin bunun dışında okul bütçesi oluşturma ile ilgili olarak herhangi bir sorumluluklarının olmadığını vurgulamışlardır. Bu nedenle okul bütçesinin gerçekten bir bütçe niteliği taşıyabilmesi açısından harcama kalemlerinin çeşitlendirilmesi ve çok yönlü harcamaya göre bütçe oluşturulması gerektiğini düşünmektedirler. Okul bütçesinin ihtiyaçlar doğrultusunda ve gerektiğinde çok yönlü harcama yapabilmeye uygun bir şekilde oluşturulması gerektiğine dikkat çeken OY 12, görüşlerini şu şekilde paylaşmıştır:

Okulda cam kırıldığında veya tamirat gerektiğinde, bunlara harcama yapmak zorundasın. Yılın başında tahminen 'bu sene 2 cam kırılır, 2 camlık masraf yazayım bütçeye' diyemezsin. İhtiyaçlara göre çok yönlü harcama yapılabilmesi gerekli. Örneğin; iş sağlığı ve güvenliği uzmanları ve sivil savunma uzmanları okula geliyor. Yangın tüpü, kauçuk gibi malzemeler alınması gerekiyor diyorlar ama ben nasıl alayım? Mesela söyledikleri bir malzeme 4500 TL, benim kantin gelirim $3750 \mathrm{TL}$. Bu yüzden okul bütçesinde ihtiyaç halinde kullanabileceğim miktarda para olmalı. Bir sürü ihtiyacı var okulun. Çok boyutlu olarak harcama kalemleri çeşitlendirilmeli bütçe oluşturulurken.

Okul yöneticileri, okul bütçesinin okulun farklı alanlardaki ihtiyaçları dikkate alınarak tasarlanması ve bu nedenle harcama kalemlerinin çeşitlendirilmesi gerektiğini 
özellikle vurgulamışlardır. Bu harcama kalemleri arasında; kırtasiye ve onarımın yanı sıra sosyal faaliyetler ve projeler de yer almaktadır. Okul yöneticileri, okul bünyesinde proje yapmak istedikleri halde kaynak yetersizliğinden yapamadıklarını dile getirmişlerdir. Bu konuda OY3; "Proje düşünüyoruz ama bu sistemde bütçe bulmakta zorlanıyoruz. Bu yüzden okul projeleri için finansör bulmaya çalışlyoruz." şeklinde görüşlerini belirtirken, OY2 ise; "Bir okulun yönetimi varsa mutlaka kendine has bir bütçesi de olmalı. Yoksa proje yapamıyoruz." açıklamasılla okul bütçesinde proje harcamalarının da yer alması gerektiğine vurgu yapmıştır.

Okul bütçesi oluşturma sürecinde her okulun kendi özellikleri doğrultusunda değerlendirilmesi ve özellikle okulun bulunduğu bölgenin, okuldaki öğrenci ve personel sayılarının dikkate alınması gerektiği ifade edilmiştir. Okul bütçesi oluşturulurken okulun özelliklerine bütüncül olarak bakılması ve bütçenin doğrudan okula aktarılması gerektiğini düşünen OY4; “Ödenek direkt bize gelse daha iyi olur. Okulun bir önceki yılda yaptığl harcamalara ve bütçesine bakılarak, okulun bulunduğu bölgenin özellikleri ve okuldaki ögrenci sayıs dikkate alınarak hazırlanan bütçe okula gönderilmeli." şeklinde görüşlerini ifade etmiştir. Okul bütçesi hazırlama sürecinde özellikle derslik ve öğrenci sayısının belirleyici olması gerektiğini belirten OY28, görüşlerini şu sözlerle paylaşmıştır:

Derslik sayısı ve öğrenci sayısı çok önemli. Diyelim ki, bir okula fatura 1500 TL gelirken aynı özelliklere sahip diğer okula $7500 \mathrm{TL}$ geliyor. Okulda su kaçağı var mesela. Bu yüzden fatura daha yüksek geliyor ama yetkisi olmadığı için her müdür bunun peşine düşmüyor ve bu parayı talep ediyor milli eğitimden. Yetkililer, aynı özelliklere sahip olmasına rağmen neden diğer okula daha fazla fatura geldiğini sormalı müdüre. Bütçe oluşturmada mutlaka okul özellikleri dikkate alınmalı ve kıyaslanmalı.

Okul yöneticileri arasında, okul bütçesi oluşturulurken okulların kendi öz gelirleri kapsamındaki okul-aile birliği bütçesinin de dikkate alınması gerektiğini belirtenler olmuştur. Aksi durumda okullara bütçe tahsis edilmesinde doğru hesaplamanın yapılamayacağını düşünmektedirler. Konuyla ilgili olarak OY17; "Okulaile birliği bütçeleri işin içine katılmalı. Şehitkamil ilçesi, IŞKUR'dan temizlik işleri için 500 hizmetli aldl. Ama bizim ilçede, okulumuza hizmetli verilmiyor. Neden? Çünkü okulumuzun 100.000 TL okul-aile birliği bütçesi var. Dolaylslyla kadrolu hizmetli dağılımının okul bütçesine göre olması çok normal. Bunu görmezden gelerek her okula aynı davranamazsınız bütçe konusunda." şeklinde deneyimlerini ve görüşlerini dile getirmiştir. Okul yöneticileri, okulların özelliklerinin ve imkânlarının bütçeleme süreçlerinde doğru değerlendirilebilmesi için evrak üzerinde değil sahaya inerek çalışmalar yapılması gerektiğini ifade etmişlerdir. Bu konuda saha çalışmalarının önemli olduğunu ve artık bu konuya gereken önemin verilmeye başlandığını düşünen OY29; "Okul bazlı bütçeleme sadece MEBBİS üzerinden yapılmaz. Sahaya inip araştırarak göreceksin okulların durumunu. Evrak üzerinde kalmamalı. Önceden okulun çatısı akıyor diye yazı yazardık ama sonuç alamazdık. İleri bir tarihe atarlardı onarım işini. Ama şimdi şube müdürleri gezerek okulların ihtiyaçlarına bakıyor. Bu doğru bütçeleme için önemli bir gelişme. ” açıklamasında bulunmuştur.

\section{OBB Uygulamasının Okul Gelişimine Katkılarına İlişkin Bulgular}

Okul yöneticilerinin, OBB uygulamasının okul gelişimine katkılarına ilişkin görüşleri Tablo 4'te sunulmuştur. 
Tablo 4

OBB Uygulamasının Okul Gelişimine Katkıları Temasına Bă̆lı Kodlamalar

\begin{tabular}{|c|c|}
\hline \multicolumn{2}{|r|}{ Tema: OBB Uygulamasının Okul Gelişimine Katkıları } \\
\hline $\begin{array}{l}\text { Alt Tema 1: Öğretim } \\
\text { Süreçlerinde Gelişim }\end{array}$ & $\begin{array}{l}\text { - Öğretim süreçlerinin niteliğine ve öğrenci başarısına daha fazla } \\
\text { dikkat edilmesi } \\
\text { - Öğrencilerin yetenek gelişimine daha fazla önem verilmesi } \\
\text { - Okul bünyesinde daha fazla proje üretilmesi }\end{array}$ \\
\hline $\begin{array}{l}\text { Alt Tema 2: Okul Yönetimi } \\
\text { Süreçlerinde Gelişim }\end{array}$ & $\begin{array}{l}\text { - Harcamaların kontrol edilmesiyle tasarruf sağlanması } \\
\text { - } \quad \text { önetim ve öğretim süreçlerine daha fazla zaman ayrılması } \\
\text { - } \text { Kaynakların etkili kullanılması } \\
\text { - } \quad \text { önetim süreçlerinde şeffaflık sağlanması } \\
\text { - Okul yönetiminin saygınlığının artması } \\
\text { - Veri girişinin daha sistemli ve disiplinli bir şekilde yapılması } \\
\text { - Aynı özelliklere sahip farklı okulların harcamalarının } \\
\text { - } \text { Sorgulanmasıyla hesap verebilirliğin sağlanması } \\
\text { - } \text { Okizillara ödenek ve destek konusunda eşit davranılmasına bağlı hesap verebilirliğin artması } \\
\text { - }\end{array}$ \\
\hline $\begin{array}{c}\text { Alt Tema 3: Sosyal Gelişim } \\
\text { ve Fiziki Donanımda } \\
\text { Gelişim }\end{array}$ & $\begin{array}{l}\text { - Okulların materyal/donanım eksikliklerinin giderilmesi } \\
\text { - Okulların ürettiği proje sayısında artış } \\
\text { - Okulların sosyal alanlardaki başarısının artmasına yönelik daha } \\
\text { fazla zaman ayrılması } \\
\text { - Sosyal ve fiziki konularda devlet ve özel okullar arasındaki } \\
\text { farklılıkların giderilmesi }\end{array}$ \\
\hline $\begin{array}{c}\text { Alt Tema 4: Okul-Çevre } \\
\text { İlişkilerinde Gelişim }\end{array}$ & $\begin{array}{l}\text { - Okulun eksikliklerinin giderilmesine bağlı olarak velilerin okula } \\
\text { - } \text { karşı tutumunda olumlu yönde değişim } \\
\text { - } \text { okulilerin okul süreçlerine daha aktif bir şekilde katılabilmek için } \\
\text { - Okul-aile birliğininin bütçesine daha az ihtiyaç duyulması } \\
\text { - Doğru bütçelemenin yapılabilmesi için okul yönetimi ve diğer } \\
\text { kurumlar arasındaki iletişimin artması }\end{array}$ \\
\hline
\end{tabular}

Tablo 4'te görüldüğü gibi, okul yöneticileri OBB uygulamasının okul gelişimine katkılarının; öğretim süreçlerine, okul yönetimi süreçlerine, sosyal faaliyetlere ve fiziki donanım kapasitesine ve okul-çevre ilişkilerine yönelik olabileceğini düşünmektedirler. OBB uygulamasının özellikle okul yönetimi süreçlerine yönelik katkısının daha fazla olabileceği ve bu şekilde yönetsel gelişimin sağlanmasının ise, öğretim süreçleri gibi diğer alanlara yansıyacağı düşünülmektedir.

Okul yöneticileri, OBB'nin öğretim süreçlerinde sağlayabileceği gelişimi; okul ihtiyaçlarının karşılanmasına bağlı olarak öğretime daha fazla zaman ayrılmasına ve öğrenci ihtiyaçlarının zamanında karşılanmasına bağlamışlardır. $\mathrm{Bu}$ şekilde sadece öğretim süreçlerine fazla zaman ayrılmayacağı, aynı zamanda öğretimin niteliğine dikkate ederek öğrenci başarısında da artış gözlenebileceği ifade edilmiştir. OBB'nin gelişim sağlaması gereken en önemli alanın öğretim olduğunu düşünen OY16; "Gerekli materyalleri zamanında temin edebilirsek öğretime daha çok zaman ayırırı, kalite 
artar. Ama 'ihtiyaçları nereden karşılayabilirim?' diye düşünürsem sürekli önceliğim ögretim olmaz. İhtiyacıma göre bütçem varsa, öğretimin kalitesi artar. Öğrencilerimiz daha başarılı olur. En önemlisi bu zaten. ” açıklamasını yapmıştır.

Okulların yeterli bütçesi olması durumunda, proje üreten okulların sayısının artacağı gerek öğretim süreçlerinde gelişim gerekse sosyal gelişim ve fiziki donanımda gelişim alt temalarında ifade edilmiştir. Okul yöneticileri, hem öğretim süreçlerinde hem de sosyal konularda proje üretme amaçlarının olduğunu paylaşmışlardır. Okulun ihtiyaçları ve eksikleri hakkında düşünmelerine gerek kalmadığı zaman, eğitimöğretime ve bu kapsamda öğrencilerin farklı alanlardaki yeteneklerine ve ilgi duydukları sosyal faaliyetlere daha fazla zaman ayırabileceklerini ve böylece proje üreten okullar haline gelebileceklerini düşünmektedirler. $\mathrm{Bu}$ doğrultuda düşünen ve OBB ile birlikte sorunlarının değişmeye başlayacağını belirten OY11, görüşlerini şu şekilde dile getirmiştir:

Yöneticiler artık 'Şuradan tasarruf edeyim de okulun şu eksiğini karşılayayım.' veya 'Okulda güvenliği sağlayacağım ama güvenlik görevlisini nasıl bulacağım?' gibi soruları düşünmek zorunda değil. Bundan sonra biz, fatura düşünmeyeceğiz. Sisteme faturayı girdikten sonra, ayrılan bütçeden ödeme yapacağız. Artık eğitim ile ilgilenebileceğiz. 'Öğrencilerimizi nasıl sosyalleştirebiliriz?', 'Nasıl proje geliştirebiliriz?' diye soracağız.

Okul yöneticileri, OBB tam anlamıyla hayata geçtiğinde okul yönetimi süreçlerinde kendilerine büyük kolaylık sağlanacağını ifade etmişlerdir. OBB'nin yönetim süreçlerine yönelik en önemli faydalarının; kaynakların etkili kullanımının sağlanması, veri girişinin daha sistemli ve disiplinli yapılması, harcamaların kontrol edilmesiyle tasarruf sağlanması ve şeffaf bir yönetim anlayışının gelişmesi olduğu belirtilmiştir. OY9, OBB uygulamasının başlangıcından itibaren veri girişine daha fazla dikkat ettiğini ve tüketim bilinci oluştuğunu; "Eskiden bütçe konusunda, faturalar için yüksek miktarlar giriyorduk. Nasıl olsa belirttiğimiz miktardan daha az ödenek gelecek diye. Şimdi faturan ne kadar geldiyse sisteme giriyorsun. Bilinçli tüketim olacak bundan sonra." şeklinde anlatmıştır. OY29 ise, OBB uygulaması ile birlikte harcamaların kontrolüne önem verdiğini ve bu şekilde hem kaynakların etkili kullanıldığını hem de bazı zamanlarda tasarruf edilebildiğini vurgulamıştır. Bu yöndeki görüşünü, şu şekilde dile getirmiştir: "Eskiden okulda geceleri de kalorifer yaklyorduk. Sabah okul sıcak olsun diye. Şimdi harcamalarımızı kontrol etmek zorunda olduğumuz için, yakmıyoruz. Fatura fazla geldiğinde sorguluyoruz artık. 'Fazla mı kullandık?' 'Nerede kaçak var?' diye." Benzer şekilde OY25 de, faturaların takibini yaparak kaynakları etkili kullanmaya çalıştığını, yaşadığı bir olay üzerinden şu şekilde anlatmıştır:

Geçen ay bir su faturası geldi, 3380 TL. Daha önce hep 800-1000 TL arasında gelirdi. Bir gariplik var dedim. Faturanın detaylarını öğrenme yetkisi bizde değil, ilçe milli eğitim müdürlüğünde. Ben durumu ilettim resmi yazıyla sonra bize bu konuda yetki verildi, faturanın takip edilmesi konusunda. Bizim okulumuzun bulunduğu yer 'mahalle' olarak geçiyor ama aslında 'köy okulu'. Faturalandırmada okulumuz, mahalle kapsamında büyük okul sayılmış ve suyun tonunun fiyatı o koddan girilmiş. Biz bu durumu öğrenince gerekenleri yaptık ve faturayı 810 TL'ye indirdik.

Okul yöneticileri, kaynakların etkili kullanılmaya çalışılmasının ve tasarruf sağlama çabası içerisinde olunmasının, yönetimde hesap verilebilirliği ve şeffaflığı beraberinde getireceğini düşünmektedirler. Okul yöneticileri arasında, yönetim ve öğretim işlerini birbirinden ayırmayarak OBB'nin aktif bir şekilde uygulanmasına bağlı olarak, yönetim ve öğretim süreçlerine daha fazla zaman ayırabileceğini belirtenler olmuştur. Bu yönde görüş beyan eden okul yöneticileri, yönetimin öğretimi geliştirmeye 
hizmet etmesi gerektiğini ve kendilerini okulun fiziki şartlarını yöneten değil öğretim süreçlerini yöneten yöneticiler olarak gördüklerini ifade etmişlerdir.

Okul yöneticileri, OBB uygulaması ile birlikte sosyal alanlarda ve fiziki donanımda gelişim gözleneceğini belirtmişlerdir. Bu kapsamda OBB'nin fiziki ve sosyal ihtiyaçların daha hızlı bir şekilde karşılanmasına yardımcı olabileceğini belirtmişlerdir. OY23, bu yöndeki düşüncesini gözlemlerinden hareketle şu şekilde anlatmıştır:

Bizler hizmetli alımı sıkıntısı ile uğraşmamalıyız. Maalesef Kasım ayı gibi İşKUR'dan işçiler geliyor. Eylülde herkes görev başında olmalı. Bu iş Haziranda okullar kapandığı an başlamalı ama ihale kanuna göre uzuyor. İhale iptalleri işi uzatıyor ve okul açıldıktan sonra hizmetli geliyor. Ama çocukları temizlikten mahrum bırakamayız. Bu durumda biz temizlik yapıyoruz. OBB uygulaması tamamen yerleştiğinde, okulun bu tür ihtiyaçlarını hızlı bir şekilde karşılayabileceğiz diye düşünüyorum.

Okul yöneticileri, sosyal ve fiziki konularla ilgili olarak zaman içerisinde devlet ve özel okullar arasındaki farklılıkların bile giderilebileceğini düşünmektedirler. Bu yönde açıklama yapan OY22, devlet okullarının kalitesinde artış gözleneceğini; "İnsanlar, çocuklarını özel okullara okul ögretimde başarılı diye göndermiyor. Özel okulların sosyal olanaklarından, hijyeninden ve teknolojik özelliklerinden dolayı gönderiyor. Okul bazlı bütçeleme devam ettikçe, devlet okulları özel okulların standartlarına kavuşabilir. En azından aradaki fark azalır. Okulların bütçesi ihtiyaçlarını karşıllyorsa, neden iyi standartlarda hizmet vermesin?" şeklinde ifade etmiştir.

Okul yöneticilerinin büyük bir çoğunluğu, bazı velilerin "okulda para istenebilir" şeklinde endişe yaşadığını ve bu nedenle okulla etkileşim içinde olmadıklarını ifade etmiştir. Okul yöneticileri, OBB'nin okul ihtiyaçlarının doğru bir şekilde giderilmesini sağlaması sonucunda, okul-aile birliğinin bütçesine bile daha az ihtiyaç duyulabileceğini belirtmişlerdir. Bu şekilde velilerin okula yönelik olumlu tutum geliştireceği ve okulla etkileşimlerinin artacağı düşünülmektedir. Okul-çevre ilişkileri kapsamında, doğru bütçelemenin yapılabilmesi için okul yönetimi ve diğer kurumlar arasındaki iletişimin artacağı da, okul yöneticileri tarafından ifade edilmiştir. Okulun borçlarına ve faturalarına ilişkin sorgulama yapmalarının, diğer kurumlarla olan ilişkilerini de artırdığını belirtmişlerdir. 
Okul Geliştirme İşlevi Açısından OBB Uygulamasının Geliştirilmesine Yönelik Önerilere İlişkin Bulgular

Okul yöneticilerinin, okul geliştirme işlevi açısından OBB uygulamasının geliştirilmesine yönelik önerileri, Tablo 5 'te yer almaktadır.

Tablo 5

Okul Geliştirme Işslevi Açısından OBB Uygulamasının Geliştirilmesine Yönelik Öneriler Temasina Băgll Kodlamalar

Tema: Okul Geliştirme İşlevi Açısından OBB Uygulamasının Geliştirilmesine Yönelik Öneriler

- Ödenek taleplerinde aşırıya kaçılmamalı

- İç ve diş denetim olmalı

- Faturalar okula zamanında teslim edilmeli

- Uygulama sürekli değiştirilmemeli

- Geciken faturaların faizini okul ödememeli

- Bütçe ve kullanma yetkisi doğrudan okula verilmeli

- Okul bütçesi temmuz veya ağustos aylarında tahsis edilmeli

- Okullarda OBB ile ilgilenecek muhasebe/işletme uzmanları olmalı

- İhtiyaçlar sistem üzerinden aylık olarak bildirilebilmeli

- Kurumlara otomatik ödeme talimatı verilmeli

- Veriler okul yöneticileri tarafindan sisteme doğru bir şekilde kaydedilmeli
- Faturalandırılamayan harcamalar sisteme yansitılabilmeli

- Okullara ayrilan bütçe harcama kalemleri çeşitlendirilerek artırılmalı

- Okul yöneticilerine OBB'ye ilişkin sorumluluklarının karşılığı verilmeli

- Okul yöneticilerine bütçeleme konusunda eğitim verilmeli

- Uygulama kapsamında ilçeler arasındaki farklılıklar giderilmeli

- Faturalara ilişkin detayları, ilçe milli eğitim müdürlüğü gibi, okul yönetimi de görebilmeli

- İlçe milli eğitim müdürlüğü destek biriminde OBB konusunda uzmanlar çalışmalı

- İlçe milli eğitim müdürlügü bünyesinde okullardan toplanan verileri analiz edecek uzmanlardan oluşan bir komisyon olmalı

- OBB’ye ilişkin yönetici eğitimleri, ilçe bünyesinde küçük gruplara yönelik verilmeli

- İlçe milli eğitim müdürlüğü bünyesinde sadece bütçeleme ile ilgilenen birimler kurulmalı

Okul yöneticileri, OBB uygulamasını olumlu yönde değerlendirdiklerini ve okul gelişimi açısından önemli bir adım olduğunu belirtmişlerdir. Ancak daha iyi sonuçlar elde edilebilmesi için, öncelikle gerçekten okula özgü bir bütçe oluşturulması amaciyla tam anlamıyla OBB yapılması gerektiğini vurgulamış ve çeşitli öneriler sunmuşlardır. $\mathrm{Bu}$ öneriler arasında, okul yöneticilerinin büyük bir çoğunluğu tarafından belirtilenler; faturaların okula zamanında teslim edilmesi, geciken faturaların faizini okulun ödememesi ve kurumlara otomatik ödeme talimatı verilmesi olmuştur. Bu konuda OY6; "Kurumlarla yapilan anlaşmalara: 'Faturaların gelmemesi durumunda oluşacak gecikme faizi kurumlardan karşllanacak.' ve 'Her ay faturalar okul idaresine teslim edilmek zorundadır.' şeklinde iki madde eklenmeli." önerisinde bulunmuştur. OY11 ise; "Kurumlarla görüşülerek otomatik ödeme talimatı verilebilir faturalar için. Bizim de iş yükümüz azalır." şeklinde görüş belirtmiştir.

Faturalandırmayan harcamaların sisteme yansıtılması yönünde öneride bulunan okul yöneticileri, aksi durumda tasarruf edebilecek şekilde ihtiyaçları karşılama yönünde çaba göstermelerinin zorlaşacağını ifade etmişlerdir. OY14, bu konuda; 
"Fatura sistemine de bir değişiklik getirilmeli. Mesela ben okulun işi için bir sucu buldum ve anlaştım. Emek için benden 1000 TL istedi. Nasıl fatura kesecek bu adam?" diyerek görüşünü paylaşmıştır.

Okul yöneticileri arasında, okul bütçesinin geç teslim edilmesinden ötürü okulun ihtiyaçlarını zamanında karşılayamadığını belirtenler olmuştur. Okul bütçesinin temmuz veya ağustos aylarında teslim edilmesinin, okul gelişiminin planlı olmasına da katkı sağlayacağı düşünülmektedir. Okuluna verilen ödeneğin yeterli olduğunu ancak zamanında gelmediğini belirten OY13; "Belirlenen ödenek yeterli ama çok geç geliyor. Her sene başında milli eğitime okul adına para gelmeli. Hatta ă̆ustos/temmuz gibi gelmeli ki biz okul açılmadan işleri bitirmiş olalım. Aralık ayında gelen para işimizi zorlaştırıyor." açıklamasını yapmıştır. Okul yöneticilerinin büyük bir çoğunluğu ise, okul bütçesinin hazırlanmasında okul yöneticilerine daha fazla yetki verilmesini ve bütçenin kullanılması konusunda da yetkilendirilmeleri gerektiğini düşünmektedir. Böyle bir durumda olumsuz tablolarla karşılaşılmaması açısından da sıkı denetim mekanizmalarının olması yönünde öneride bulunmuşlardır. Bu yönde görüş sahibi olan OY10; "Okul bazlı bütçeleme mutlaka olmalı. Olumlu bir adım ama para kullanma yetkisi okul müdürlerine verilmeli. Getirilen her yeni uygulama, sorumluluğumuzu artırıyor ama yetkimizi artırmıyor." demiştir. Aynı konuda OY22; "Bütçe oluşturmada benim rolüm yoksa ve ben bu bütçeyi kullanamıyorsam, bu tam olarak okul bazlı bütçeleme olmaz. Bütçe derken, tüm harcamalart içeren bir bütçeden bahsediyorum. Bize yetki verilmeli ama iç/dış denetimlerle sağlam bir kontrol olmall." diyerek görüş ve önerilerini paylaşmıştır.

Okul yöneticileri, asıl görevlerinin eğitim ve öğretimle ilgilenmek olduğunu ve bu nedenle okullarda OBB ile ilgilenecek muhasebe veya işletme alanında uzmanlar olması gerektiğini ifade etmişlerdir. Bu konuyla ilgili olarak OY9; "Okul bazlı bütçelemenin bu alanda uzman olmayan kişilerin elinde çok da sağllkl yürütülmediğini düşünüyorum. Öğretmenlerin ve ögrretmenlikten gelen idarecilerin işi değil.” derken, OY23; "Daha çok tasarruf sağlanmast için bu işi uzmanlar yapmall. Muhasebe, işletme alanında uzmanlar ilgilenebilir bu süreçle." önerisinde bulunmuştur. Aynı zamanda okul yöneticileri arasında, bu konuda uzman olmadıkları için, OBB uygulaması geliştikçe bütçeleme konusunda daha çok zorluk yaşayabileceğini düşünenler bulunmaktadır. Bu nedenle bu yönde düşünen okul yöneticileri, bütçeleme ile ilgilenen ve birebir diyalog kurabilecekleri birimlerin ilçe milli eğitim müdürlükleri bünyesinde olması gerektiğini ifade etmişlerdir.

İlçe milli eğitim müdürlüklerindeki destek birimlerinde, OBB ile ilgili olarak yeterli sayıda uzman çalışması, bazı okul yöneticileri tarafından gerekli görülmektedir. $\mathrm{Bu}$ yönde düşünen okul yöneticileri, destek birimlerinde çok fazla çalışan olmadığını belirterek ihtiyaç halinde beklemeden uzman desteğine ulaşmak istemektedirler. Bazı okul yöneticileri ise, OBB'nin mevcut durumunda henüz okul harcamalarına ve okulların fiziki özelliklerine yönelik verilerin toplanılması aşamasında olunduğu için, uzman sayısının az olmasının bir sorun oluşturmadığını ve etkili bir şekilde çalışıldığını ifade etmiştir. Ancak ileride okullara ilişkin toplanan verilerin analizine geçilirse, ilçe milli eğitim müdürlükleri bünyesinde analiz konusunda uzmanların yer alacağı bir komisyonun oluşturulmasının faydalı olacağını dile getirmişlerdir. OBB kapsamında analiz çalışmalarının mutlaka yapılması gerektiğini düşünen OY15; "Şu an sorun yok ama ileride analizde sorun olabilir. Analiz olmayacaksa veri toplamanın da anlamı yok. 
Analizler için komisyon oluşturulacağı söyleniyor. Ama bu komisyonlarda uzmanların görev alması daha doğru olacaktır." şeklinde görüşünü dile getirmiştir. Analizlerin doğru bir şekilde yapılabilmesi için ise, okul yöneticilerinin okullara ilişkin verileri farklı sistemlere doğru ve tutarlı bir şekilde girmesinin önemli olduğunun altı çizilmiştir. Bu konuyla ilgili olarak OY4; "Okul yönetim sisteminde, MEÍS'de ve MEBBİS'deki diğer modüllerde bilgiler doğru girilirse analiz doğru yapılabilir. Önemli olan, bu bilgilerin tutarlı olmasıdır." demiştir.

Okul yöneticilerinin en önde gelen isteklerinden birisi de, okullara ayrılan bütçenin harcama kalemleri çeşitlendirilerek artırılması olmuştur. Okul yöneticileri, OBB'nin mevcut halinde sisteme girilen elektrik, su ve doğal gaz faturalarının ödendiğini ve okul bütçesinin bu şekilde değerlendirildiğini ifade etmişlerdir. Okul bütçesinin artabilmesi için ise, okulların farklı alanlardaki ihtiyaçlarına dair ödenek talebinin OBB kapsamında yapilabilmesi istenmektedir. OY26, bu konudaki ihtiyaçlarını; "Okulun farkl ihtiyaçları için ödenek gelmiyor. En çok toner ve fotokopi için gerekli. Bu ihtiyaçlarımızı okul-aile birliği bütçesinden karşıllyoruz." şeklinde belirtirken, OY8 de benzer şekilde; "Biz, bir yıl içinde en az 10.000 sayfa fotokopi çekmişiz ama bunun için gelen bir ödenek yok.” demiştir.

\section{Tartışma, Sonuç ve Öneriler}

$\mathrm{Bu}$ araştırmada; OBB uygulamasına ilişkin mevcut durum, OBB'nin geliştirilmesi için atılması gereken adımlar ve OBB'nin okul gelişimine nasıl katkıda bulunduğu ve bulunabileceği incelenmiştir. Okul yöneticilerinin görüşleri doğrultusunda, OBB uygulamasının okul geliştirme aracı olarak kullanılabileceği ortaya çıkmıştır. Literatürde de bu sonucu destekleyen farklı ülkelerde yapılmış araştırmaların sonuçları bulunmaktadır. Bu konuda Cheng (2006), OBB'nin okul özelliklerini geliştirmede faydalı olduğunu belirtirken; Yang (2008), OBB'nin genel okul etkililiği üzerinde önemli etkileri olduğu sonucuna ulaşmıştır. Shih (2006) ve Line (2005), OBB'nin okulların birçok özelliğini geliştirmeye yardımcı olduğunu; Chen (2002) ve Lin (2006) ise, OBB'nin okul etkililiğinin anlamlı ve pozitif bir yordayıcısı olduğunu saptamıştır. OBB sonucunda okulların kendi önceliklerini belirleyebilmeleriyle birlikte okul bakımına ilişkin daha duyarlı bir yaklaşımın oluştuğu ve okullara sunulan finansal bilgilerin kalitesinde sürekli iyileşme olduğu gözlemlenmiştir (Humphrey \& Thomas, 1986, aktaran Caldwell \& Spinks, 1988). OBB'nin okul performansına ve gelişimine yönelik bu tür katkıları, çeşitli ülkelerde farklı alanlardaki eğitim politikalarına da yön vermektedir. Bu tür eğitim politikalarının bir örneği olarak; Wohlstetter ve Van Kirk, (1995), OBB'nin yüksek performans gösteren okulların oluşturulmasına yardımcı olması amacıyla okul bölgelerinin çalışmalarını yansıtan derecelendirme süreçlerinin işe koşulduğunu belirtmiştir. OBB'nin okul geliştirme çalışmalarına farklı eğitim politikalarını biçimlendirerek de katkı sağlayabileceği düşünüldüğünde, amacına hizmet edecek şekilde tasarlanmasının ve uygulanmasının önemi daha iyi anlaşılabilmektedir.

Araştırmaya katılan okul yöneticileri, OBB uygulamasını okul gelişimini sağlama açısından faydalı olarak değerlendirmekte ancak OBB'nin geliştirilmesi yönünde beklentileri bulunmaktadır. Aynı zamanda OBB kapsamında, daha fazla yetki ve sorumluluk sahibi olmak istemektedirler. $\mathrm{Bu}$ araştırmada incelenen OBB uygulaması, birçok ülkede gözlenen OBB uygulamalarının aksine; yerel toplulukların, okul müdürlerinin, öğretmenlerin, ailelerin ve sendikaların katılımıyla oluşturulan okul 
komisyonları aracılığıyla yürütülmemektedir. Hatta mevcut uygulamada, okul müdürünün oldukça sınırlı yetkisi ve görevi bulunmaktadır. Hazırlanan okul bütçesinin kapsamında ise, okulların her türlü ihtiyacına yer verilememektedir. Dolayısıyla araştırmaya katılan okul yöneticileri, OBB'nin okul gelişimine hizmet edebilmesi açısından uygulamanın tam anlamıyla okul bazlı hale getirilmesi gerektiğini düşünmektedirler. Araştırmanın bu bulgularına benzer şekilde Raz ve Ratner (2013), OBB'yi de kapsayan okul bazlı yönetime geçişte atılan yeni adımlar konusunda okul yöneticilerinin olumlu görüşe sahip olduklarını saptamıştır. Araştırmalarında okul müdürlerinin yönetimsel yetkinliklerinin artması açısından daha geniş bir özerklik arzusu içerisinde oldukları belirlenmiştir. Elbette merkezi yönetim anlayışının yer aldığı bir eğitim sisteminde tam anlamıyla bir OBB uygulamasına geçebilmek kolay değildir. Okullar için merkezi bütçelemeden OBB'ye geçişte dramatik bir değişiklik olacaktır. OBB'nin uygulanmadığı durumlarda müdürler; öğretim, bina ve bina malzemeleri için sadece birkaç küçük bütçe kalemini kontrol ederler. Okul düzeyinde bütçelemeye geçildiğinde ise bu kontrol; okul, aile ve sosyal işbirliklerine dayalı toplanan fonları da içerebilir (Wohlstetter \& Buffett, 1991). Bu nedenle OBB'ye aşamalar halinde geçmeye dönük çalışmaların yapılması ve sürecin gözlenmesi, uygulamanın pozitif çıktılar vermesi açısından uygun bir yaklaşım olacaktır. Nitekim bu araştırmaya katılan okul yöneticileri de, yapılan çalışmaların OBB'nin tam olarak uygulanmasına basamak oluşturduğunu düşünmektedirler. Hatta mevcut OBB uygulamasında okullara ait verilerin toplanması da, ilerideki uygulamalara hazırlık olarak değerlendirilmektedir. Ancak toplanan verilerin birden fazla veri tabanına (sisteme) girilmesi zorunluluğunun OBB'nin daha sistematik bir şekilde işlemesinin önünde engel teşkil ettiği düşünülmektedir. Dolayısıyla sürecin gözlemlenmesi ve paydaş görüşlerinin dikkate alınması, tamamen "okul bazlı" bir sisteme geçilmesi durumunda birçok konuda iyileştirme yapılmasına katkıda bulunacaktır.

Okul yöneticileri, OBB'nin okul gelişimine katkılarına dair açıklamalarında yönetim süreçlerine ve öğretim süreçlerine yönelik katkıları çoğunlukla bir arada değerlendirmişlerdir. OBB'nin yönetim süreçlerinde şeffaflı̆̆ 1 ve hesap verebilirliği artıracağı, kaynakların daha etkili kullanımının sağlanacağı ve bu şekilde okul yönetimi süreçlerinde gelişim gözlenebileceği düşünülmektedir. Aynı zamanda öğretim süreçlerinin niteliğinde ve öğrenci başarısında iyileşme elde edilebileceği vurgulanmıştır. Bu konuda Clarke (2002), kaynakların daha verimli kullanılmasının ve yerel ihtiyaçların daha kısa sürede karşılanmasının öğrenciler açısından öğrenme çıktılarını iyileştireceğini ifade etmiştir. OBB aracılı̆̆ıyla yönetim ve öğretim süreçlerinde eş zamanlı bir gelişim elde edilebileceğine ilişkin çeşitli araştırma sonuçları bulunmaktadır. Barrera-Osorio, Fasih ve Patrinos (2009), OBB'nin daha etkili ve şeffaf kaynak kullanımını sağladığını ve bu şekilde eğitimde kalite artışı elde edildiğini belirtmiştir. Aynı zamanda, OBB'nin hesap verebilirliği artırarak öğrencilerin öğrenme çıktılarının iyileştirilmesine katkıda bulunduğunu ifade etmiştir. Santibañez, AbreuLastra ve O'Donoghuec (2014) tarafından yürütülen çalışmada ise, gelişmekte olan birçok ülkede öğrencilerin öğrenimini iyileştirme girişimlerinde kullanılan ve okul konseylerine nakit para aktaran okul tabanlı yönetim reformlarının uygulanması üzerinde durulmuştur. Araştırma sonucunda, programın öğrenci çıktıları üzerinde olumlu etkileri olduğu ve okul bazlı anlayışa bağlı olarak ilk kez nakit para alan okullara daha fazla fayda sağladığı görülmüştür. Tüm bu bulgular birlikte 
değerlendirildiğinde, OBB'nin herhangi bir okul gelişim sürecine yansımasının diğer gelişim süreçlerine de pozitif girdiler sağladığı anlaşılmaktadır. Bu nedenle OBB'nin okul geliştirme aracı olarak incelenmesinde, okul gelişiminin farklı boyutlarının bütüncül bir anlayışla değerlendirilmesi daha doğru olabilir.

Okul yöneticilerinin görüşleri, okul gelişimini destekleyen bir okul bütçesi oluşturma sürecinde öğrenci ve personel sayısı gibi okula ait özellikler ile okulun bulunduğu bölgenin dikkate alınmasının gerekliliğine işaret etmektedir. Okul bütçesinin oluşturulmasında dayanak noktasının doğru bir şekilde belirlenmesi, OBB'nin okul gelişimine ne yönde katkıda bulunacağını da belirleyebilmektedir. Bu konuyla ilgili olarak Fermanich, Odden ve Archibald (2000), OBB'nin öğrenci tabanlı bir bütçeleme olduğunu ve öğrenci bazlı formül kullanılarak hazırlanan yeni bütçenin üç yıl boyunca izlenmesi sonucunda öğrenci başarısında önemli ölçüde iyileşme gözlendiğini tespit etmiştir. Dolayısıyla önemli olan, OBB'nin bütçe oluşturma ve kullanma süreçlerinde hangi dayanaklar doğrultusunda gerçekleştirildiğidir. Bütçe oluşturma sürecinde, bütçe kullanım alanlarının okulların farklı ihtiyaçları doğrultusunda çok yönlü olarak hazırlanmas1, okul geliştirme süreçlerine çok boyutluluk ve esneklik kazandırabilecektir. Nitekim bu araştırmada da okul yöneticileri, okulun ihtiyaçları doğrultusunda farklı harcama kalemlerine uygun ödeneklerin olması ve artan bütçenin iade edilmemesi gerektiğini ifade etmişlerdir. Benzer şekilde Line (2005), OBB'nin; okulların yıllık bütçeleme planı, okul idaresinin temel talepleri, okulların yıllık etkinlikleri ve okulun idari işlerinin gelişimi temelinde olması gerektiğini belirtmiştir. Aynı zamanda okulların, toplam bütçelerini kullanabilmesi için sınırlı da olsa bir özerkliğe sahip olması ve yıllık bütçenin geri kalanını gelecek yıla devredebilmesi gerektiği sonucuna varmıştır. Cranston (2000) tarafından yapılan araştırmada ise okul müdürleri, okul merkezli bütçeleme faaliyetlerinin; okullarının özel ihtiyaçları doğrultusunda plan yapmalarına, yönetmelerine ve kaynakları dağıtmalarına olanak sağladığını belirtmiş̧lerdir. Bu nedenle OBB uygulamasının geliştirilmesine yönelik atılacak adımlarda, bu araştırmaya katılan okul yöneticilerinin de belirttiği gibi, okulların farklılaşan çok boyutlu ihtiyaçları dikkate alınmalıdır. Harcama kalemlerindeki çok boyutluluk ve esneklik, OBB uygulamasının başarısı açısından anahtar olarak görülmektedir. Goertz ve Stiefel (1998), OBB'nin “okulların işlerini farklı şekillerde yapması için itici güç" olma vazifesini tam olarak gerçekleştiremediğinin altını çizmiştir. Paranın geleneksel bütçeleme yöntemlerinde olduğu gibi; sınıf mevcudunu azaltmak, sosyal hizmetleri genişletmek, sanat ve müzik programlarını zenginleştirmek ve büyük programların yeniden yapılandırılması için ekipman ve malzeme satın almak için kullanıldığını belirtmiştir. Bu nedenle okul bütçesinin okul gelişimi doğrultusunda çok yönlü kullanımının sağlanması kritik öneme sahiptir.

Araştırmada okul yöneticilerinin, okul geliştirme işlevi açısından bütçe oluşturma ve kullanma yetkisinin okul komitelerine veya birden fazla paydaşa değil, doğrudan okul yönetimine verilmesini istedikleri anlaşılmıştır. Bu süreçlerde il ve ilçe milli eğitim müdürlüklerinin daha çok kontrole ve desteğe dayalı bir rolü olması gerektiği düşünülmektedir. Her ne kadar araştırmaya katılan okul yöneticilerinin bu yönde bir isteği veya görüşü olmasa da, birçok ülkedeki OBB uygulamasında okul komiteleri görev yapmaktadır. Okul komiteleri, okul performansını izleyerek geliştirme bütçesi de dâhil olmak üzere, yıllık bütçeleri onaylamakta ve aylık mali raporları 
incelemektedir (Barrera-Osorio, Fasih, \& Patrinos, 2009). Örneğin; Endonezya'daki OBB uygulamasında; okul müdürü, öğretmenler, okul çalışanları ve veliler işbirliği içinde çalışmaktadırlar. Bütçenin yürütülmesinde tek sorumlu okul müdürü değildir. Okul müdürü, faaliyetlerde düzenli olarak harcanan paraların ve OBB fonlarının yönetiminin etkinliğini sağlamaktan sorumludur (Rahayu, Ludigdo, Irianto, \& Nurkholis, 2015). Wohlstetter ve Van Kirk (1995) ise ABD, Kanada ve Avustralya'daki OBB uygulamalarını incelemiştir. Araştırmada okul bölgelerinin merkezi yönetimden güç yetkisi almasına rağmen, okulların bölge yönetimlerinden çok az yetki alabildikleri ortaya çıkmıştır. Dolayısıyla bu bulgu, OBB'nin aktif ve etkili bir şekilde uygulanabilmesi açısından okul yönetimlerinin yetkilerinin genişletilerek güçlendirilmesi gerektiğini göstermektedir. Bu noktada okul komiteleri, OBB sürecinde okulları yönetsel açıdan güçlü kılan bir oluşum olarak değerlendirilmektedir. Nitekim Line (2005), Tayvan'daki okullarda yaptığı araştırmasında; yerel yönetimin baş yöneticisi, denetçi ve okul müdürünün desteği ile eğitim bütçesine ilişkin talebe yönelik formül tasarlayan komitenin kurulmasının, OBB'nin yürütülmesi açısından temel faktör olduğu sonucuna varmıştır. Bu bulgular birlikte ele alındığında, ilçe milli eğitim müdürlüklerine denetim ve destek rolü verilerek bütçeleme yetkisinin doğrudan okul yönetimine verilmesi sonucunda, okul yönetiminin tek başına sahip olduğu etkileme gücünün sınırlılığından dolayı istenilen çıktıların elde edilemeyebileceği düşünülebilir. Aynı zamanda bu tür bir uygulamanın süreçlerin denetimini de sınırlandırabileceği göz önünde bulundurulmalıdır.

OBB, örtük veya açık bir şekilde okul müdürlerinin eğitim sonuçlarından sorumlu olduğunu vurgulamaktadır. Oldukça fazla ihtiyaç duyulan kaynaklara yönlendirme yeteneğinin, bir okulun ihtiyaçlarını en iyi bilen kişi olduğu düşünülen okul müdüründe olduğu kabul edilmektedir (Anthony \& Young, 2007). Bu nedenle OBB kapsamında okul müdürlerine tam yetki verilmese de, uygulamanın okul gelişimine hizmet edebilmesi için okul müdürlerinin $\mathrm{OBB}$ ve bütçeleme hakkında yeterli düzeyde bilgi sahibi olmaları gerekmektedir. Okul yöneticilerinin OBB uygulamalarındaki rollerini yerine getirilebilmeleri, büyük oranda yeterli bilgiye ve beceriye sahip olmalarına bağlıdır. Çünkü okul müdürlerinin OBB uygulamaları kapsamında iş tanımlarında bütçe kontrolü açısından bir değişiklik olacak ve sorumlulukları artacaktır. Bütçe kontrolündeki rollerinin artması ise, okul müdürlerine liderlik fırsatı sunmaktadır ve bu durum, etkili okul özellikleri ile ilgili literatür ile son derece tutarlılık göstermektedir (Purkey \& Smith, 1983). Bu nedenle okul yöneticilerinin bütçeleme ve finansman alanlarındaki yetki ve sorumluluklarında gözlenecek artışın liderlik potansiyellerinde gelişim sağlayacağı ve bu şekilde etkili okul oluşumuna katkıda bulunabileceği düşünülebilir. OBB, okul sahasındaki yönetim yapısını değiştirmeden uygulanabilmektedir. Her ne kadar OBB sürecinde bütçe hazırlığı ve mali hesap verebilirliğin ekstra yükü okul müdürüne verilse de, bu sorumluluklar müdürün okuldaki görev tanımına dâhil edilebilir (Chan, 1997). Dolayısıyla OBB aracılığıyla okul müdürlerinin liderlik kapasitelerinin geliştirilebilmesi, görev tanımlarının genişletilmesi ile mümkün olabilmektedir. Ancak bu yönde bir genişletme yapılmadan önce, okul müdürlerinin bütçeleme ve OBB konusunda nitelikli bir eğitim sürecinden geçmeleri önem taşımaktadır. Nitekim bu araştırmaya katılan okul yöneticileri de, bu konularda nitelikli bir eğitime ihtiyaç 
duyduklarının ve hatta ileride OBB'nin kapsamı genişledikçe, daha fazla ihtiyaç duyacaklarının altını çizmişlerdir.

Okul yöneticilerinin OBB sürecinde yetkilerinin genişletilmesi ve bu kapsamda eğitime ihtiyaç duymaları, denetim faaliyetlerinin gerekliliğini gündeme getirmektedir. Araştırmaya katılan okul yöneticileri de, OBB'nin okul gelişimine tam anlamıyla hizmet edebilmesi için iç ve dış denetim mekanizmaları olması gerektiğini belirtmişlerdir. Williamson ve Snow (2013), OBB'de teori ve uygulama arasındaki boşluğun; müdürler için eğitim eksikliği ve zayıf iç kontrollerden kaynaklandığını belirtmiştir. $\mathrm{Bu}$ konudaki en önemli nedenin ise; okul yönetim kurullarındaki bütçe kontrolünün belirleyicisi olarak okul müdürlerine aktarılan yasal ve politik sorumluluklar olduğunu ifade etmiştir. Dolayısıyla okul yöneticilerinin sorumlulukları artarken denetim mekanizmalarının ve eğitim olanaklarının da geliştirilmesi gerekmektedir. Nitekim Line (2005), OBB'nin hem idari kontrol hem de mesleki kontrol modellerini içermesi gerektiğini vurgulamıştır.

Denetim mekanizmalarının eksikliği ile ilgili olarak Vernez, Karam ve Marshall (2012), okul konseylerinin rolünün çoğunlukla okul müdürlerinin önceden aldıkları kararları onaylama ile sınırlı kaldığını saptamıştır. Goertz ve Stiefel (1998) ise, OBB'de katılımcı karar verme sürecinin etkin olması gerekirken, müdürlerin harcamalar üzerinde kayda değer bir güce sahip olduklarını gözlemlemiştir. Oysaki OBB'de karar verme gücünün kaynakları hem dişsal hem de içseldir. Dış faktörler güçlü olduğu ölçüde okulun iç faktörleri de, güç yapısına ve karar verme sürecine yansımaktadır (Iatarola \& Stiefel, 1998). Müdürler tarafından alınan mikro kararların etkilerini tanımlamakta ve kaynak tahsisinin nasıl yapıldığını açıklamakta yaşanacak güçlükler sürece zarar verebilir (Roza, 2008). Kötü veya etkisiz kontroller, fonların ve varlıkların yanlış kullanım riskini artırabilir. Bu riski azaltmak için okul kurulları, fonların ve fiziki varlıkların kullanımında müdürlerin takdir yetkisini sınırlayabilir (Clover, Jones, Bailey, \& Griffin, 2004). Bu nedenle ülkemizdeki mevcut OBB uygulamasının geliştirilmesi ve tamamen okul bazlı duruma geçilmesi halinde, okul yöneticilerinin karar alma süreçlerini denetleyen sağlam denetim modellerinin oluşturulması gerekmektedir.

Her ne kadar bu araştırmada okul yöneticileri, OBB'nin kaynakların etkili kullanımını sağlayarak okullarda kaliteyi ve verimliliği artıracağını öngörseler de, OBB'nin her zaman merkezi bütçelemeden daha verimli olmadığ 1 da belirtilmektedir. $\mathrm{Bu}$ nedenle belirli bir OBB uygulamasının olası verimlilik sonuçlarını fayda-maliyet açısından analiz etmek yararlı olacaktır (Chan, 1997). Bu konuda Goertz ve Stiefel (1998), OBB uygulamalarında adem-i merkeziyetçi yapıdan kaynaklı olarak okulların, öğrencilerin ve vergi mükelleflerinin ihtiyaçlarının karşıladığına dair hiçbir garanti sağlanamadığını ifade etmiştir. Bu nedenle OBB'nin okul gelişimine hizmet edebilmesi için nasıl bir şekilde yapılandırılması gerektiği üzerinde düşünülmesi gereken önemli bir konudur. Araştırmaya katılan okul yöneticilerinin özellikle vurguladığı gibi; OBB’nin mevcut haliyle tam olarak okul temelli bir anlayışla uygulanmadığı ve bir geçiş döneminde bulunulduğu düşünülürse, istenen verimliliği sağlayabilecek bir OBB uygulamasının tasarlanması için gerekli çalışmaların yapılabileceği söylenebilir.

Araştırmanın bulguları genel olarak değerlendirildiğinde, OBB'nin bir okul geliştirme aracı olarak okulların çok boyutlu geliştirilmesine hizmet edebileceği sonucuna varılmaktadır. Bunun mümkün olabilmesi için sosyal, ekonomik ve kültürel açıdan okulların içinde bulunduğu şartlara uygun bir yapılanma sürecine gidilmesi 
gerektiği ortaya çıkmıştır. Okul yöneticilerinin görüşleri, okul gelişimine hizmet edebilecek OBB uygulamasının diğer ülke örneklerinden biraz daha farklı olması gerektiğini göstermiştir. OBB'nin çok paydaşlı bir yapıdan ziyade ağırlıklı olarak okul yönetimlerinin idaresinde gerçekleştirilmesi uygun bulunmaktadır. Her ne kadar mevcut OBB uygulaması pozitif yönde değerlendirilse de, özellikle okul bütçesinin kapsamı genişletilmediği ve okulların ihtiyaçlarına göre farklılaştırılmadığı sürece, OBB ile okul gelişiminden ziyade sadece okulların işleyişsinin devamlılığının sağlanabileceği anlaşılmaktadır.

Araştırmanın bulgularına dayalı olarak, öncelikle OBB'nin uygulama sürecinin yapılandırılmasına ilişkin okul yöneticilerinin ve okul paydaşlarının görüşleri doğrultusunda gerekli düzenlemelerin yapılması önerilmektedir. OBB'nin tam anlamıyla bir okul geliştirme aracı olarak kullanılabilmesi için okulların ihtiyaçlarına bağlı olarak farklılaştırılmış biçimlerde uygulanması sağlanabilir. Okul yöneticilerinin OBB ve bütçeleme konusunda ayrıntılı olarak bilgilendirilmeleri ve bu süreçte ilçe milli eğitim müdürlüklerinin bünyesinde aktif destek alabilecekleri uzmanlardan oluşan birimlerin kurulması faydalı olabilir. OBB sürecinde okul yöneticilerinin iş yükünü hafifletmek ve daha sistemli bir çalışma düzeni oluşturabilmek için veri girişlerinin tek bir sistem üzerinden yapılması önerilmektedir. 


\section{Summary}

Purpose and Significance: Expectations of improving the education quality in schools and satisfying the ever-changing needs of schools timely require multifaceted improvement of school performance with the participation of internal and external stakeholders of schools. System level policies affecting school processes have become the focus of school development along with in-school processes. Therefore, several countries have implemented various financing policies in an attempt to improve both efficiency in education and school performance in recent years. School-Based Budgeting (SBB) giving school management authorization to decide on resource allocation according to the needs of both school and students (Cheung \& Kan, 2009) can be considered among these policies.

In Turkey, the policy of SBB has been adopted in such a way that it comprises preschools, primary schools and secondary schools which are within Directorate General for Basic Education's province following of the statements included in Tenth Development Plan (The Ministry of Development, 2013) and Ministry of National Education (MoNE) Strategic Plan (MoNE, 2015). It is aimed that "increasing authority and responsibilities of provincial directorate of national education, district national education directorate and school management in budget processes" through SBB (MoNE Directorate General for Basic Education, 2017, p.1). Although steps to implementation of SBB policy have been taken, it is also seen that current implementation does not reflect the characteristics of SBB policy exactly. Despite the fact that SBB implementation does not give school-based financial management authority to school administrators exactly, it is an important development due to the fact that school management has an active role in budget processes and the needs of schools are satisfied more effectively in this way. Considering the contributions of SBB to school development stated in the literature, it is understood that examining of the benefits of SBB for school development in Turkey is an important issue. Investigating changes and innovations which should be made in the current implementation is also necessary for the success of SBB.

In this study, it was aimed to determine the opinions of school administrators on the implementation of SBB and the contributions of SBB to school development. The problems of the study in accordance with this aim were as follows: (1) What are the opinions of school administrators on current SBB implementation? (2) What do school administrators think regarding the contributions of SBB to school development?

Method: The study was conducted through descriptive approach and qualitative methods and techniques were used in the study. The study group consisted of 29 primary and secondary school administrators working in Gaziantep province. Among the participants of the study, 15 school administrators have worked in primary schools and 14 of them have worked in secondary schools. While 12 school administrators are principal, 17 of them are assistant principal. Data of the study were obtained through semi structured interviews and focus group interviews. Semi structured interviews were performed with the participation of 15 school administrators. Two sessions of focus group interviews were performed with the participation of 14 school administrators. Content analysis was performed on obtained data. Five main themes named "reflections of SBB implementation on the authority and responsibilities of school management", 
"usage of Ministry of National Education Information Systems fund monitoring module within SBB implementation", "process of setting school budget within SBB", "contributions of SBB implementation to school development" and "recommendations for improvement of SBB implementation in terms of school development function" were determined during the content analysis process.

Results: School administrators participating in the study consider SBB implementation helpful in terms of ensuring school development. However, they have expectations of improving SBB. They want to have more authority and responsibilities within the scope of SBB. According to school administrators, SBB implementation should be completely school-based in order to make sure that SBB serves to school development. Contributions of SBB to management process and teaching process were mostly considered together in administrators' explanations regarding contributions of SBB to school development. It was determined that SBB can improve transparency and accountability in management processes, ensure effective use of resources and therefore development can be observed in school management processes. It also became evident that the quality of teaching processes and student success can be improved.

Discussion and Conclusions: It was revealed that SBB implementation can be used as a school development tool according to the opinions of school administrators. In the literature, there are several studies conducted in different countries and the results of these studies support this finding. While Cheng (2006) stated that SBB is beneficial to develop school characteristics, Chen (2002) and Lin (2006) determined that SBB is a significant and positive predictor of school effectiveness. The opinions of school administrators point out school characteristics such as number of student and school personnel and the district where school is located should be taken into consideration during the process of setting school budget supporting school development. Proper determination of reference point for setting school budget can also determine that how SBB contributes to school development. On this subject, Fermanich, Odden and Archibald (2000) ascertained that SBB is a student-based budgeting and significant improvement is observed in student success as a result of monitoring the new budget which is set by using student-based formula. When evaluating the findings of the study generally, it was concluded that SBB should be structured in accordance with social, economic and cultural conditions of school and school environment. The opinions of school administrators show that SBB which can serve for school development should be structured differently from SBB implementations of other countries. It is considered appropriate that SBB should be conducted under the governance of school management rather than multi-stakeholder committees.

Based on the findings of the study, it is suggested that SBB can be performed differently depending on different needs of each school in an attempt to use it as a school development tool completely. Departments consisted of experts should be established within district directorate of national education and school administrators should be able to get support from these departments. 


\section{Kaynakça}

Anthony, R., \& Young, D. (2007). Management control in nonprofit organizations (7th ed.). New York: McGraw-Hill.

Baines, W. (2007). Common ground across the divide: Financial management policies of schools in contrasting public education systems. Paper presented at the 47th Annual Conference for Accounting and Finance Association, Australia and New Zealand, (AFAANZ), Queensland, Australia.

Barrera-Osorio, F., Fasih, T., \& Patrinos, H. A. (2009). Decentralized decision making in schools: The theory and evidence on school-based management. Washington, DC: World Bank.

Briggs, K. L., \& Wohlstetter, P. (2003). Key elements of a successful school-based management strategy. School Effectiveness and School Improvement, 14(3), 351372.

Caldwell, B. J., \& Spinks, J. M. (1988). The self-managing school. London: Routledge.

Chan, L. (1997). School-based budgeting: A cost-benefit model. Reports - Evaluative.

Retrieved

from https://eric.ed.gov/contentdelivery/servlet/ERICServlet?accno=ED422628

Chen, C. C. (2002). A study on relationship between school-based management and school effectiveness in elementary and junior high schools (Unpublished master's thesis). National Hualien University of Education, Hualien, Taiwan.

Cheng, C. L. (2006). The feasibility of school-based finance management in junior high schools, under condition of educational adequacy (Unpublished doctoral dissertation). National Kaohsiung Normal University, Kaohsiung, Taiwan.

Cheung, S. M. C., \& Kan, F. L. F. (2009). Teachers' perceptions of incorporated management committees as a form of school-based management in Hong Kong. Asia Pacific Education Review, 10(2), 139-148.

Clarke, S. (2002). Understanding small school leadership: Listening to the practitioners. Practicing Administrator, 24(3), 28-29.

Clover, M. W., Jones, E. B., Bailey, W., \& Griffin, B. (2004). Budget priorities of selected principals: Reallocation of state funds. NASSP Bulletin, 88(640), 69-82.

Cranston, N. (2000). The impact of school-based management on primary school principals: An Australian perspective. Journal of School Leadership, 10(3), 214232 .

Creswell, J.W. (2002). Research design: Qualitative, quantitative and mixed methods approaches (2nd ed.). Thousand Oaks, CA: Sage Publications.

Çankaya, İ., \& Gün, C. (2016). Okul merkezli yönetime ilişkin özel okul yöneticilerinin görüşleri. Ĕ̆itim ve Öğretim Araştırmaları Dergisi, 5, 38-43.

DeGrow, B. (2015) Colorado student-based budgeting on the rise. Denver, Colorado: Independence Institute. Retrieved from https://www.i2i.org/wpcontent/uploads/2015/08/IP-2-2015-2.pdf.

Eldeniz, F. (2018). Temel eğitime tahsis edilen ödeneklerin yönetiminde yetki devri yaklaşımı (Uzmanlık Tezi, Kalkınma Bakanlığı, Sosyal Sektörler ve Koordinasyon Genel Müdürlüğü). http://www.sbb.gov.tr/wp-content/uploads/2018/11/FerayEldeniz.pdf adresinden ulaşı1mıştır. 
Fermanich, M., Odden, A., \& Archibald, S. (2000). A case study of district decentralization and site-based budgeting: Cordell place school district. Consortium for Policy Research in Education. Retrieved from https://eric.ed.gov/contentdelivery/servlet/ERICServlet?accno=ED454624.

Field, P.A., \& Morse, J.M. (1985). Nursing research. The application of qualitative approaches. Beckenham Kent: Croom Helm.

Goertz, M. E. (2001). Comprehensive school reform and school-based budgeting in New Jersey. Paper presented at the 26th Annual Meeting of the American Education Finance Association, Cincinnati, $\mathrm{OH}$.

Goertz, M. E., \& Stiefel, L. (1998). School-level resource allocation in urban public schools. Introduction to special issue. Journal of Education Finance, 23(4), 435446.

Hadderman, M. (2002). School-based budgeting. Teacher Librarian, 30(1), 27-29.

Hoşgörür, V., \& Arslan, İ. (2014). Okul örgütünün finansal kaynaklarının yönetimi sorunu (Yatağan İlçesi örneği). Trakya Üniversitesi Ĕ̆itim Fakültesi Dergisi, 4(1), 91-102.

Hsieh, C. C., \& Hsieh, Y. S. (2005). A study on the school-based management of elementary schools. Journal of National Taipei University of Education, 18(1), 6394.

Iatarola, P., \& Stiefel, L. (1998). School-based budgeting in New York city: Perceptions of school communities. Journal of Education Finance, 23(4), 557-576.

Kalkınma Bakanlığı (2013). Onuncu kalkınma planı (2014-2018). http://www.kalkinma.gov.tr/Lists/Kalknma\%20Planlar/Attachments/12/Onuncu\%2 0Kalk\%C4\%B1nma\%20Plan\%C4\%B1.pdf adresinden ulaşılmıştır.

Karakütük, K., \& Özdoğan Özbal, E. (2017). Bütçe yönetimi yeterliklerine ilişkin genel lise müdürlerinin görüşleri. International Journal of Human Sciences, 14(4), 40974111.

Lambert, V.A., \& Lambert, C.E. (2012). Editorial: Qualitative descriptive research: An acceptable design. Pacific Rim International Journal of Nursing Research, 16(4), 255-256.

Leininger, M. (1994). Evaluation criteria and critique of qualitative research studies. In J. M. Morse (Ed.). Critical issues in qualitative research methods (pp.95- 115). Thousand Oaks, CA: Sage Publications.

Levin, H. M. (1987). Finance and governance implications of school-based decisions. Paper presented to the National Advisory Committee of the national policy study of "The Teacher: Ally in Educational Reform" of the Work in America Institute, New York City.

Lin, K. F. (2006). A study of the relationship among school-based management, organizational climate and school effectiveness in elementary schools in Kaohsiung city (Unpublished master's thesis). National Sun Yat-Sen University, Kaohsiung, Taiwan.

Line, Y-W. (2005). A study on school-based budgeting of elementary schools in Taoyuan county (Unpublished master's thesis). National University of Tainan, Tainan, Taiwan. 
Loeb, S., Dynarski, S., McFarland, D., Morris, P., Reardon, S., \& Reber, S. (2017). Descriptive analysis in education: A guide for researchers. (NCEE 2017-4023). Washington, DC: U.S. Department of Education, Institute of Education Sciences, National Center for Education Evaluation and Regional Assistance.

Manning, K. (1997). Authenticity in constructivist inquiry: Methodological considerations without prescription. Qualitative Inquiry, 3(1), 93-115.

MEB (2015). Milli Eğitim Bakanlı̆̆ 2015-2019 stratejik planı. http://sgb.meb.gov.tr/meb_iys_dosyalar/2015_09/10052958_10.09.2015sp17.15imz asz.pdf adresinden ulaşılmıştır.

MEB Temel Eğitim Genel Müdürlüğü (2017). Okul bazlı bütçeleme kılavuzu. https://igdir.meb.gov.tr/meb_iys_dosyalar/2017_01/24142809_klavuz.pdf adresinden ulaşılmıştır.

Morrow, S.L. (2005). Quality and trustworthiness in qualitative research in counseling psychology. Journal of Counseling Psychology, 52(2), 250-260.

Moser, M. (1998). School-based budgeting: Increasing influence and information at the school level in Rochester, New York. Journal of Education Finance, 23(4), 507531.

Özdoğan Özbal, E. (2017). Genel liselerde bütçe yönetimine ilişkin karşılaştırmalı bir çözümleme. Eğitim Bilimleri Araştırmaları Dergisi, 7(2), 151-170.

Patton, M. (1990). Qualitative evaluation and research methods (pp. 169-186). Beverly Hills, CA: Sage.

Picus, L. O. (1997). Using school-level finance data: Endless opportunity or bottomless pit?. Journal of Education Finance, 22(3), 317-330.

Polansky, H. B. (1998). Equity and SBM: It can be done. School Business Affairs, 64(4), 36-37.

Purkey, S. C., \& Smith, M. S. (1983). Effective schools: A review. Elementary School Journal, 83(4), 426-452.

Rahayu, S., Ludigdo, U., Irianto, G., \& Nurkholis (2015). Budgeting of school operational assistance fund based on the value of gotong royong. Social and Behavioral Sciences, 211, 364-369.

Raz, T., \& Ratner, D. (2013). Transition of elementary schools to self-management: Perceptions and attitudes concerning the program in its first year of implementation: Qualitative Findings. Jerusalem: Ministry of Education, The National Authority for Measurement and Evaluation.

Richards, J. C., \& Schmidt, R. (2002). Longman dictionary of language teaching and applied linguistics (3rd ed.). London: Longman.

Rossmiller, R. A. (1997). Equity, adequacy, and variable spending in public spending. In B.S. Kogan (Ed.), Common schools, common futures: A working consensus for school renewal (pp.166-184). New York: Teachers College, Columbia University.

Roza, M. (2008). Allocation anatomy: How district policies that deploy resources can support (or undermine) district reform strategies. Research Brief. Seattle: Center on Reinventing Public Education, University of Washington. Retrieved from www.crpe.org/sites/default/files/pub_sfrp_aa_may08_0.pdf. 
Sandelowski, M. (1986). The problem of rigor in qualitative research. Adv Nurs Sci, $8(3), 27-37$.

Santibañez, L., Abreu-Lastra, R., \& O’Donoghuec, J. L. (2014). School based management effects: Resources or governance change? Evidence from Mexico. Economics of Education Review, 39, 97-109.

Shih, H.-Y. (2006). A study on school-based financial management of elementary schools. (Chia Nan University of Pharmacy \& Science Report: CNTE9502). Tainan, Taiwan: Chia Nan University of Pharmacy \& Science.

Srithongrung, A. (2018). An evaluation of performance-based budget reform in Asian countries. International Journal of Public Administration, 41(4), 257-267.

Tooley, S. T., \& Guthrie, J. (2003). Devolved school-based financial management in New Zealand: Observations on the conformity patterns of school organisations to change. Discussion Paper Series 216. Palmerston North: School of Accountancy, Massey University.

Vernez, G., Karam, R., \& Marshall, J. H. (2012). Implementation of school-based management in Indonesia. Santa Monica, CA: RAND Corporation. Available from https://www.rand.org/pubs/monographs/MG1229.html

Williamson, A. L., \& Snow, D. (2013). Bridging theory and practice: The landscape of public management reforms in local school district budgeting. Public Performance and Management Review, 37(1), 154-187.

Wohlstetter, P., \& Buffett, T. (1991). School-based management in big city districts: Are dollars decentralized too? Unpublished manuscript presented at Annual Meeting of the American Educational Research Association, Chicago, IL.

Wohlstetter, P., \& Van Kirk, A. (1995). School-based budgeting: Organizing for high performance. Paper presented at the Annual Meeting of the American Educational Research Association, San Francisco, CA. Retrieved from https://eric.ed.gov/contentdelivery/servlet/ERICServlet?accno=ED384953

Wolf, Z.R. (2003). Exploring the audit trail for qualitative investigations. Nurse Educator, 28(4), 175-178.

Yang, W. C. (2008). The correlative study on school-based finance management, the equality of educational opportunity and school efficiency (Unpublished master's thesis). National Sun Yat-Sen University, Kaohsiung, Taiwan.

Yau, H. K., \& Cheng, A. L. F. (2011). The effectiveness of 'Financial Planning and Control' in school-based management. E-Journal of Organizational Learning and Leadership, 9(2), 49-62.

This is an Open Access article distributed under the terms of the Creative CommonsAttributionNonCommercial-ShareAlike 4.0 International (CC BY-NC-SA 4.0). For further information, you can refer to https://creativecommons.org/licenses/by-nc-sa/4.0/ 